\title{
Revisiting parameter sensitivities in the Variable Infiltration Capacity model
}

\author{
Ulises M. Sepúlveda ${ }^{1}$, Pablo A. Mendoza ${ }^{1,2}$, Naoki Mizukami ${ }^{3}$ and Andrew J. Newman ${ }^{3}$ \\ ${ }^{1}$ Department of Civil Engineering, Universidad de Chile, Santiago, Chile \\ $5 \quad{ }^{2}$ Advanced Mining Technology Center, Universidad de Chile, Santiago, Chile \\ ${ }^{3}$ National Center for Atmospheric Research, Boulder, CO, USA
}

Correspondence to: Pablo A. Mendoza (pamendoz@uchile.cl)

\begin{abstract}
Despite the Variable Infiltration Capacity (VIC) model being used for decades in the hydrology community, there are still model parameters whose sensitivities remain unknown. Additionally, understanding the factors that control spatial variations in parameter sensitivities is crucial given the increasing interest to obtain spatially coherent parameter fields over large domains. In this study, we investigate the sensitivities of 43 soil, vegetation and snow parameters in the VIC model for 101 catchments spanning the diverse hydroclimates of continental Chile. We implement a hybrid local-global sensitivity analysis approach, using eight model evaluation metrics to quantify sensitivities, with four of them formulated from runoff time series; two characterizing snow processes, and the remaining two based on evaporation processes. Our results confirm an

15 over-parameterization for the processes analysed here, with only 12 (i.e., 28\%) parameters found as sensitive, distributed among soil (7), vegetation (2) and snow (3) model components. Correlation analyses show that climate variables - in particular, mean annual precipitation and aridity index - are the main controls on parameter sensitivities. Additionally, our results highlight the influence of the leaf area index on simulated hydrologic processes - regardless on the dominant climate types and the relevance of hard-coded snow parameters. Based on correlation results and the interpretation of spatial sensitivity patterns, we provide guidance on the most relevant parameters for model calibration according to the target processes and the prevailing climate type. Overall, the results presented here contribute to improved understanding of model behaviour across watersheds with diverse physical characteristics that encompass a wide hydroclimatic gradient from hyper-arid to humid systems.
\end{abstract}

\section{Introduction}

25 Over the past four decades, the increasing demand for more realistic spatial representations of water storages and fluxes across large domains has motivated the development of more complex physics-based models (e.g., Niu et al., 2011; Clark et al., 2015; Lawrence et al., 2019). The progress in this field has been partly facilitated by new observational datasets (e.g., McCabe et al., 2017; Berg et al., 2018) and advances in computing (see discussion on tradeoffs in Clark et al., 2017), enabling hydrological characterizations at national (e.g., Tian et al., 2017; Zink et al., 2017), continental (e.g., Xia et al., 2012; Abbaspour et al., 2015) and global (e.g., Schmied et al., 2014; Arheimer et al., 2020) domains. 
Although spatially constant parameters can be used for large domain applications, improving model realism requires the specification of parameter values that reflect spatial heterogeneities in landscape properties. Because increasing model complexity is often associated with a larger number of parameters, many models rely on lookup tables to assign soil thermal and hydraulic parameters, and vegetation optical and physiological parameters for each modelling unit (e.g., Mitchell et al.,

35 2004; Yang et al., 2011). However, parameter uncertainties may be considerable (Rosero et al., 2010; Hou et al., 2012), and such problem is exacerbated by the existence of parameters that, despite being "adjustable" (e.g., runoff generation parameters), remain fixed and hard-coded (Mendoza et al., 2015a; Cuntz et al., 2016).

To address overparameterization problems that are typical in environmental models, sensitivity analysis has become a key tool that provides information on which parameter values are the most influential for the dynamics of specific model responses

40 (Razavi and Gupta, 2015). The outcomes of sensitivity analysis not only help to improve understanding of model functioning, but also to inform decisions regarding parameter estimation problems. The literature provides many examples of sensitivity analysis studies with process-based hydrological models, including the Biosphere-Atmosphere Transfer Scheme, BATS (Bastidas et al., 1999); TOPKAPI (Foglia et al., 2009); PRMS (Mendoza et al., 2015b), the Noah land surface model (Bastidas et al., 2006; Rosero et al., 2010); Noah-MP (Mendoza et al., 2015a; Cuntz et al., 2016), the Simple Biosphere model, SiB3

45 (Prihodko et al., 2008; Rosolem et al., 2012); the MESH modelling system (Razavi and Gupta, 2016), the Community Land Model, CLM (Göhler et al., 2013; Massoud et al., 2019) and the Variable Infiltration Capacity (VIC) model (e.g., Demaria et al., 2007; Melsen et al., 2016), which is one of most popular modelling platforms in the hydrology community (Addor and Melsen, 2019).

The VIC model (Liang et al., 1994; Hamman et al., 2018) has been used for myriad applications all over the world, including 50 snow modeling (Andreadis et al., 2009; Chen et al., 2014), streamflow forecasting (Wood et al., 2005; DeChant and Moradkhani, 2014), water balance studies (Mizukami et al., 2016; Vásquez et al., 2021), extreme event characterization (Melsen et al., 2019); land use change impacts (Chawla and Mujumdar, 2015) and climate change impact assessments (e.g., Vano and Lettenmaier, 2014; Chegwidden et al., 2019). Despite the large number of parameters contained in VIC - either 'free' (e.g., the infiltration shape parameter 'INFILT', the exponent in baseflow curve) or 'observable' (e.g., leaf area index) , many studies have relied on the calibration of only two or three soil-related parameters (Huang and Liang, 2006; Chawla and Mujumdar, 2015). Conversely, other authors have advocated for characterizing parameter sensitivities using different approaches, sensitivity metrics, and including different parameters. For example, Liang \& Guo (2003) assessed the sensitivity of annual runoff, annual evapotranspiration (ET), annual mean soil moisture, and annual mean sensible heat flux to variations in five soil and vegetation parameters at three experimental locations (i.e., point scale), finding that sensitivities varied with 60 climatic and physiographic site characteristics. Demaria et al. (2007) examined sensitivities in simulated catchment-scale runoff responses using lumped VIC configurations, a Monte Carlo method, and five objective functions computed for four basins with varying hydroclimates. They concluded that (i) three (out of ten) soil parameters dominated the simulated runoff response; (ii) the INFILT parameter and the drainage parameter (Expt $\mathrm{i}_{\mathrm{i}}$ depended strongly on local hydroclimatology, and (iii) that the baseflow model formulation is overparameterized. 
65 Subsequent studies aiming at calibrating the VIC model to simulate observed catchment-scale responses have revisited its parametric sensitivity. Mendoza et al. (2015b) applied the distributed evaluation of local sensitivity analysis method (DELSA, Rakovec et al., 2014) to find the parameters that provided the largest sensitivities in root mean squared errors (RMSE) between simulated and observed streamflow; they showed that 9 (out of 34) parameters provided the largest sensitivities in three subcatchments from the Upper Colorado River basin. Melsen et al. (2016) also used the DELSA method to find influential parameters in three catchments located in Switzerland, identifying four (out of 28) very sensitive parameters for three calibration metrics. Wi et al. (2017) applied the method of Morris (1991) to quantify parameter sensitivities on the NashSutcliffe efficiency (NSE; Nash and Sutcliffe, 1970) with daily flows, finding 6 soil parameters and two temperature threshold parameters as the most influential (out of 15). Gou et al. (2020) characterized the sensitivities provided by 13 soil parameters across 14 catchments in China, finding that INFILT, Depth1 and Depth2 dominated streamflow responses. Lilhare et al. (2020)

75 applied the Variogram Analysis of Response Surfaces (VARS) method (Razavi and Gupta, 2016) to examine the sensitivities of three streamflow performance metrics to variations in six soil parameters across 10 catchments in Canada, finding that INFILT and Depth2 parameters dominated streamflow responses. Yeste et al. (2020) quantified relative sensitivities provided by five soil parameters to water balance components across 31 basins in the Iberian Peninsula, concluding that INFILT and Depth 2 control runoff components and evapotranspiration (ET). Finally, Melsen and Guse (2021) characterized VIC parameter 80 sensitivities for a historical (1985-2008) and future (2070-2093) period in 605 catchments of the conterminous United States finding that, in the historical period, Rmin, Depth2 and Expt 2 controlled average streamflow, while Ds, DsMAX, and many more parameters influenced streamflow timing. Melsen and Guse (2021) also projected increased (decreased) sensitivities to Depth2 (snow parameters) for the future period when examining average streamflow, and increased (decreased) future sensitivities to deep soil (snow) parameters when looking at discharge timing.

85 Table 1 summarizes the main characteristics of parameter sensitivity studies with VIC. Note that we have excluded a recent study conducted by Sheikholeslami et al. (2021), who quantified parameter sensitivities in modified version of VIC specifically, using a slow linear reservoir (Gharari et al., 2019) model instead of the traditional ARNO formulation. Most the studies listed in Table 1 focused on streamflow responses, attributing the largest sensitivities to a few soil parameters (Demaria et al., 2007; Gou et al., 2020; Lilhare et al., 2020). Only two studies - also characterizing streamflow responses - have included

90 a large number of soil, vegetation and snow related parameters (Melsen et al., 2016; Mendoza et al., 2015b). Additionally, only two studies (Chaney et al., 2015; Bennett et al., 2018) aimed to characterize sensitivities across model grid cells. Chaney et al. (2015) quantified the effects of 9 parameters on annual flow biases, runoff seasonality and daily flow extremes at $1^{\circ}$ resolution grid cells across the globe. Bennett et al. (2018) examined sensitivities of projected changes in water balance components to variations in 46 VIC parameters, across a suite of $\sim 7-\mathrm{km}$ grid cells in the Colorado River basin. Sensitivity

95 analyses at higher resolutions is particularly relevant for the hydrology community, considering recent developments in meteorological datasets (e.g., Tang et al., 2021), global, gridded runoff datasets (e.g., Do et al., 2018; Ghiggi et al., 2019) and the increasing interest to improve the calibration density - i.e., use high resolution data in the calibration process - in distributed hydrology and land surface models (Yang et al., 2019). 
In this paper, we quantify VIC parameter sensitivities across 5,574 grid cells $\left(0.05^{\circ} \times 0.05^{\circ}\right)$ covering 101 catchments located in continental Chile, including a suite of 43 standard and hard-coded parameters, and a set of metrics that span different runoff, ET and snow processes. The results presented here contribute to improved understanding of model behaviour across watersheds with diverse physical characteristics, spanning from hyper-arid to humid hydroclimates. With this, we seek to answer the following research questions:

1. Are there other vegetation and snow parameters, either standard or hard-coded, affecting simulated runoff responses in VIC?

2. What are the effects of standard and hard-coded parameters on other simulated processes?

3. How do parameter sensitivities relate with local climatic and physiographic characteristics?

\section{Study domain and data}

In this work, we select 101 catchments with near-natural hydrological regimes from the CAMELS-CL data set (AlvarezGarreton et al., 2018). The selected basins span a total area of $139,350 \mathrm{~km}^{2}$ - i.e., $19 \%$ of the territory of continental Chile -, and meet the following criteria: (i) a maximum threshold value of $5 \%$ for the relationship between the annual volume of water assigned as permanent consumptive rights and the average annual flow (Table 3 in Alvarez-Garreton et al., 2018), and (ii) absence of large reservoirs within each catchment. The location, hydroclimatic and land cover characteristics across the domain are shown in Figure 1, and the descriptors used to characterize the grid cells are listed in Table 2. These catchments cover a wide range of physiographic attributes, with drainage areas spanning 100-7,500 km², mean elevations ranging $119-4824 \mathrm{~m}$ above sea level, mean slopes varying from 52 to $306 \mathrm{~m} \mathrm{~km}^{-1}$, and markedly different land cover types, ranging from completely covered by native forest or grassland to fully covered by impermeable land. Moreover, the selected basins represent the diversity in hydroclimatological conditions across the country. For example, the hydrology of catchment 2101001 (Rio Loa before Lequena dam, Figure 2a) is influenced by arid conditions between March and November, and Altiplanic winter events triggering runoff increases between December and March; towards the south, there is a transition from arid to semi-arid conditions (see progression in Figure 2b-c), with precipitation events occurring mostly during fall and winter (especially MayAugust), favoring the accumulation of snow in the headwaters of Andean catchments, and thus snowmelt-driven regimes. Catchments 7115001 (Palos River at junction with Colorado River; Figure 2d) and 8317001 (Biobio River at Rucalhue; Figure 2e) reflect the transition towards mixed regimes, with larger contributions of winter rainfall events to runoff. Finally, catchment

1259129002 (Cautin River at Cajon; Figure 2f) has a rainfall-dominated hydrological regime, with the largest runoff volumes during the winter season (i.e., June-September).

In this study, meteorological forcing data is obtained from various sources. Time series of daily precipitation and maximum, average, and minimum daily temperature are obtained from the CR2MET meteorological dataset, introduced in DGA (2017), which provides data for continental Chile at a horizontal resolution of $0.05^{\circ} \times 0.05^{\circ}(\sim 5 \mathrm{~km})$ for the period 1979-2016. The precipitation product builds upon a statistical post-processing technique that uses topographic descriptors and simulated 
meteorological variables from ERA-Interim (Dee et al., 2011) and ERA5 (C3S and Copernicus Climate Change Service (C3S), 2017) as predictors, and daily precipitation records as the predictand. A similar approach is used to generate time series of daily maximum and minimum temperatures, including additional predictors from MODIS land surface products. Daily precipitation and temperature variables are disaggregated into 3-hourly time steps using the sub-daily distribution provided by ERA-Interim. Finally, relative humidity and wind speed were obtained from a blend between ERA-Interim and ERA5, which was subsequently rescaled at the CR2MET horizontal grid through spatial interpolation. It is important to note that this product combination was created because ERA5 was not available during the entire study period (1985-2015) at the time of data acquisition (early 2018, where only 2010-2016 data was available). However, the updated reanalysis information, despite the short time coverage, was included due to various developmental improvements.

\section{Methods}

\subsection{Hydrological model}

The Variable Infiltration Capacity (Liang et al., 1994, 1996) model (version 4.1.2.g) is a semi-distributed, physically-based hydrological model that simulates snow accumulation and melt, evapotranspiration (ET), canopy interception, surface runoff, baseflow, and other hydrological processes at daily or sub-daily time steps. In VIC, the domain of interest can be spatially

145 discretized into grid cells. Sub-grid land-use type variability is accounted for by providing vegetation tiles and the fractional areas, for which water and energy balance equations are solved separately; then, model states and fluxes are spatially averaged to provide results at the pixel scale. In VIC, each grid cell can have up to three soil layers: the two top layers represent the interaction between moisture and vegetation, and the bottom soil layer is used to simulate baseflow processes. VIC does not incorporate an aquifer at the bottom of the soil column, nor lateral exchange of fluxes between grid cells. Finally, snowpack dynamics are simulated by a two-layer mass and energy balance model (Cherkauer et al., 2003; Andreadis et al., 2009), where the surface layer solves the energy exchange between the snowpack and the atmosphere, and the lower layer stores the excess snow mass from the upper surface layer.

\subsection{Parameters considered for sensitivity analysis}

We considered a suite of 43 parameters (Table 3) to incorporate most of soil, vegetation, and snow processes simulated by 155 VIC. It should be noted that three of the snow parameters are not exposed to model users (NEW_ALB, ALB_AA and $A L B \_T H A$ ), although the associated relationships and default values were proposed decades ago (USACE, 1956). For those parameters with monthly variations, we examined sensitivities using regularization "superparameters" (Tonkin and Doherty, 2005), also called multipliers (Pokhrel and Gupta, 2010), which are uniformly applied over all monthly values. Hence, multipliers are used for the leaf area index $(L A I)$; vegetation albedo $(A L B)$; vegetation roughness length $(R O U)$ and vegetation displacement $(D I S)$.

160 Despite some of these parameters are considered observable, a non-negligible degree of uncertainty may be involved in their determination; an example is the LAI parameter (Tian et al., 2002; Fang et al., 2012, 2013), whose implementation in many 
hydrology and land surface models is simplified through static monthly values. Assumptions like this motivate us to explore the sensitivity of this type of parameters, which may have the potential to be included in the calibration process.

Despite the aim to include the largest possible number of parameters, some of them were discarded for different reasons. For example, a few soil parameters (e.g., soil bubbling pressure) are not active unless the frozen soil algorithm is turned on. We also excluded the parameter trunk_ratio - i.e., the ratio of total tree height that is trunk (no branches) - because it is activated only in those grid cells with forest (i.e., vegetation class with overstory, spanning $22 \%$ of our study domain) as land cover type. Finally, we found five mutually related soil parameters that do not allow independent variations: soil bulk density $(b d)$; soil particle density $(s d)$; fractional soil moisture content at the critical point $\left(\theta_{c r}\right)$, fractional soil moisture content at the wilting point $\left(\theta_{\mathrm{wp}}\right)$ and residual soil moisture $\left(\theta_{r}\right)$. These parameters are related following:

$\theta_{c r} \geq \theta_{w p} \geq \frac{\theta_{r}}{\left(1-\frac{b d}{s d}\right)}$

From these five parameters, we only include $\theta_{r}$ and $b d$ because (1) perturbing $\theta_{r}$ and $b d$ values did not affect numerical solutions, and (2) Bennett et al. (2018) showed that $\theta_{c r}, \theta_{w p}, b d$ and $s d$ did not have substantial effects on model simulations. Finally, those parameters that showed little or no sensitivity in the initial phases of the study were purposely discarded.

\subsection{Sensitivity analysis approach}

We used the Distributed Evaluation of Local Sensitivity Analysis (DELSA; Rakovec et al., 2014) method, which is a derivative-based, hybrid local-global approach. DELSA combines elements from the method of Morris (Morris, 1991), the Sobol' method (Sobol', 2001) and regional sensitivity analysis (Hornberger and Spear, 1981), and provides robust results with a fewer number of model simulations compared to variance-based global methods such as Sobol'. Although our implementation only examines first-order sensitivities (as in Mendoza et al., 2015b; Zegers et al., 2020; among other studies) DELSA has unexplored potential to quantify parameter interactions, which could be achieved by including additional terms in the local total variance (Sobol' and Kucherenko, 2010).

Consider a transformation $f$ and a vector $\theta$ with k parameters, which provides a metric $\Psi$ describing model output:

$\Psi=f(\theta), \quad f: R^{k} \rightarrow R$,

185 Given a sample point $\theta^{*}$ in the parameter space, the gradient for metric $\Psi$ and parameter $\theta_{j}$ around this point - i.e., $\left.\frac{\partial \Psi}{\partial \theta_{j}}\right|_{\theta^{*}}-$ is considered a measure of local sensitivity. In this work, we follow Rakovec et al. (2014) and compute such gradient using a forward, finite difference approach with $1 \%$ change in the parameter value:

$\left.\frac{\partial \Psi}{\partial \theta_{j}}\right|_{\theta^{*}}=\frac{\Psi\left(\theta_{j}^{*}+0.01 \theta_{j}^{*}\right)-\Psi\left(\theta_{j}^{*}\right)}{0.01 \theta_{j}^{*}}$ 
In equation (3), $\Psi\left(\theta^{*}\right)$ is a signature measure of hydrologic behavior, formulated by contrasting model output at the point $\theta^{*}$ with that obtained from a reference parameter set $\theta^{\text {ref }}$ in the grid cell of interest (see section 3.3.2 for details). The first-order sensitivity measure for the $j^{\text {th }}$ parameter is calculated at each sample point as:

$S_{j}^{L}=\frac{\left(\frac{\partial \Psi}{\partial \theta_{j}} \mid \theta^{*}\right)^{2} s_{j}^{2}}{V_{L}\left(\theta^{*}\right)}$,

Where $s_{j}^{2}$ is the a priori parameter variance of the $j^{\text {th }}$ parameter, and $V_{L}\left(\theta^{*}\right)$ is the linearized local variance:

$V_{L}\left(\theta^{*}\right)=\sum_{j=1}^{k}\left(\left.\frac{\partial \Psi}{\partial \theta_{j}}\right|_{\theta^{*}}\right)^{2} s_{j}^{2}$

195 Finally, $s_{j}^{2}$ is obtained from the variance of a uniform distribution (Rakovec et al., 2014), which is $\frac{1}{12}\left(\theta_{j, \max }-\theta_{j, \min }\right)^{2}$. The first-order sensitivity indices vary between 0 and 1 , and the sum of first-order sensitivities from all parameters at each sampling point is equal to 1 . Local sensitivities can be examined through their cumulative frequency distribution across the parameter space, or by computing a specific statistical property. Here, we quantify the relative contribution of a specific parameter using the area above the curve of the full frequency distribution:

\subsection{Performance metrics}

We use eight model evaluation metrics to quantify the sensitivity of simulated hydrological processes to variations in model parameters. The notation, brief description, mathematical formulation, and physical process associated with each metric are detailed in Table 4. These metrics are computed by contrasting model output from sampling points produced for DELSA, with a reference, national scale dataset with simulated states and fluxes obtained from the National Water Balance database (DGA, $2018,2019,2020$ ) for the historical period 1985-2015. Such dataset was developed by running the VIC model at the same grid discretization employed here (i.e., $0.05^{\circ} \mathrm{x} 0.05^{\circ}$ ), using a combination of CR2MET version 2.0, ERA-Interim and ERA5 output as meteorological forcings. The spatially distributed parameter fields for our reference simulation were developed via parameter regionalization, based on the similarity between possible donor catchments - whose parameters were calibrated individually (Vásquez et al., 2021) - and each grid cell across the domain, following Beck et al. (2016). The reader is referred to Vásquez et al., (2021) and DGA (2018, 2019, 2020; in spanish) for more details on individual model calibration and parameter regionalization procedures used to generate the reference simulation.

Four evaluation metrics are formulated from runoff time series. The first objective function is the root-mean-square error (RMSE), which is a standard metric that emphasizes high flows. The second metric selected is the transformed-root-meansquare error (TRMSE), for which the simulated and observed runoff time series are transformed using a Box-Cox transformation to emphasize low flows (Misirli et al., 2003). The third objective function is the flow duration curve (FDC) 
midsegment slope difference (FMS), which represents the variability, or flashiness, of the flow magnitudes, so it measures how well a model captures the distribution of the mid-level flows. A steep slope of the FDC indicates flashiness of the streamflow response, whereas a flatter curve indicates a relatively damped response and a higher storage (Yadav et al., 2007; Casper et al., 2012). The fourth evaluation metric is the runoff ratio difference (RR), considered as a measure of the general water balance and, therefore, as a signature of the evapotranspiration model component (Mendoza et al., 2015b).

We use two metrics to characterize snow cover processes: the difference in long-term simulated peak SWE, and the difference in snow cover duration, quantified by the number of days with snow on the ground (Mizukami et al., 2014). Finally, we include two metrics based on evaporation fluxes. The sublimation difference (SUBL) emphasizes the net sublimation from the snowpack surface, and the plant transpiration difference (TRANSP).

\subsection{Experimental setup}

We apply the DELSA method in 5,574 grid cells across continental Chile, which are contained within the 101 catchments described in section 2. In each grid cell, hydrologic model simulations are conducted at 3-hourly time steps for a 12-year period (April/1999 - March/2011), with the first two years used to initialize model states (i.e., spin-up period). The model is run in full energy balance mode, which means that both energy and water balances are solved, and 3-hourly outputs are aggregated to daily time steps for subsequent analyses.

In this study, we use the Latin hypercube sampling (LHS) method to obtain 200 sample points across the parameter space, for which first-order sensitivity indices are computed. LHS is an efficient simulation technique, especially suitable for statistical and sensitivity calculations (Vořechovský, 2015). To stratify the parameter space, we sample uniformly in a 43-dimensional hypercube, and map onto the parameter space using the inverse cumulative distribution function of each parameter's prior. Since DELSA is used here, all parameter distribution functions are assumed to be uniform. The computational cost of applying DELSA at each cell is $N_{l}(k+1)=8,800$ model runs, where $N_{l}$ is the number of sample points (200) and $k$ is the number of parameters (43), and the total number of models runs required for this study is 49,051,200.

In this paper, a parameter is considered redundant or insensitive when the median value of the integrated first-order sensitivity index (i.e., median $I S_{j}^{L}$ ) across all grid cells is smaller than 0.05 for at least seven of the eight evaluation metrics listed in Table 4. Parameter sensitivity results are also examined per metric (section 3.4) and grid cell climate type based on the aridity index (UNEP, 1997; Verbist et al., 2010; Table 5).

Finally, we use the Spearman rank correlation coefficient, $r_{s}$, to measure the degree of association between parameter sensitivities and physiographic/hydroclimatic characteristics listed in Table 2. These attributes were chosen due to their ability to improve the prediction of hydrological signatures (Addor et al. 2018) and because they are relatively easy to obtain. 


\section{Results and discussion}

\subsection{Intra and inter-basin variability in parameter sensitivities}

Figure 3 shows the cumulative distribution functions of sensitivity indices $S_{j}^{L}$ for combinations of evaluation metric and parameter. Each panel located in the first six rows includes the CDFs of all the grid cells contained in a specific basin, and the last row in Figure 3 comprises the CDFs of all grid cells across six hydroclimatically different catchments - also displayed in Figures 1 and 2. The results reveal high parametric sensitivities for RMSE-INFILT in basins located in northern Chile (arid regime) and lower sensitivities along central-southern catchments, while the opposite behavior is observed for TRMSE $D s M A X$, FMS - DsMAX and RR - LAI (i.e., increasing sensitivities towards the south). Such dependence between hydroclimatic basin characteristics and parameter sensitivities was also reported by Demaria et al. (2007). Gou et al. (2020) also found that sensitivities were strongly related to environmental characteristics, including climate, vegetation, soil and topographic features. Figure 3 also enables the comparison between intra-catchment (top six rows) and inter-catchment (bottom row) variability in parameter sensitivities. For the sample of basins included here, one can note that inter-basin variability in sensitivities is larger than intra-basin variability in runoff-related metrics. Nevertheless, for some combinations of metric and parameter intra-catchment variability is comparable to inter-basin variations in parametric sensitivities. For example, the spread in the CDFs displayed for SUBL-zO_SNOW at basin 8317001 (Biobio River at Rucalhue) - characterized by a wet hydroclimate - is comparable to the spread arising from all basins (see same column, last row).

To further illustrate intra-basin differences in parameter sensitivities, Figure 4 and Figure 5 show the spatial distribution of the $I S_{j}^{L}$ indices for the leaf area index ( $\left.L A I\right)$ and the snow albedo parameter $A L B_{-} T H A$, respectively, over a cluster of sub-humid and humid basins located in southern Chile. For the $L A I$ parameter (Figure 4), a west-east gradient in $I S_{j}^{L}$ is observed for RMSE (high flows), TRMSE (low flows) and FMS (flashiness of runoff), with increasing sensitivity to $L A I$ variations towards the coast, while an inverse pattern is observed for the same metrics and ALB_THA (i.e., larger sensitivities towards the Andes, Figure 5). For PeakSWE, SUBL, and - to a smaller degree - SnowLength, LAI yields larger sensitivities in vegetated areas, where snow accumulates during winter (Figure 4), matching those locations where forest is the dominant land cover type, which is also the only vegetation class with overstory (e.g. trees). Notably, very large variations in PeakSWE sensitivities to $L A I$ are observed over relatively short distances due to differences among grid cells in the fraction of land cover defined as forest. Such dependence among SWE sensitivities, $L A I$ and canopy fractions was also reported by Bennett et al. (2018). Figure 4 also shows that LAI does not yield a clear sensitivity pattern in RR and TRANSP throughout this subdomain, although $I S_{j}^{L}$ values are higher for RR. For this metric, there are spatial singularities where the sensitivity is minimal or null since, in these areas, the fraction of ground cover defined as bare soil increases considerably, reaching up to $100 \%$ of bare soil $(L A I \sim 0)$ in some grid cells.

The results presented in Figure 5 reinforce the idea that hard-coded parameters should be exposed to users (Mendoza et al., 2015a; Cuntz et al., 2016). In particular, Figure 5 shows the large effects of $A L B \_T H A$ variations on SnowLength (with a very 
pronounced east-west gradient) and, to a smaller degree, on PeakSWE and SUBL. $A L B$ _THA also affects runoff-based metrics along the Andes, especially on simulated high (RMSE) and low (TRMSE) flows.

\subsection{Identification of most sensitive parameters}

Figure 6 displays box plots comprising $I S_{j}^{L}$ results from all grid cells in the study domain, for each parameter and evaluation metric (displayed in different panels). The results show that $72 \%$ of the parameters analysed (i.e., 31) yield little sensitivities for the metrics examined here. Conversely, a suite of 12 sensitive parameters are associated to soil (INFILT, Ds, DsMAX, Ws, Expt2, Depth2, Depth3), snow (NEW_ALB, ALB_THA, and $\left.A L B \_A A\right)$, and vegetation (Rmin and $\left.L A I\right)$ processes. Figure 7

shows the spatial variability of $I S_{j}^{L}$ for the 12 parameters identified as the most sensitive across the 101 basins of continental Chile.

For the case of high flows (RMSE), low flows (TRMSE), and flashiness of runoff (FMS), the parameters identified as sensitive are INFILT, Ds, DsMAX,Ws, Expt2, Depth2, and Depth3 (see top three panels in Figure 6). The parameter INFILT controls the shape of the variable infiltration capacity curve (Zhao et al., 1980; Wood et al., 1992), and thus the partitioning of rainfall or snowmelt into infiltration and surface runoff. A higher INFILT value yields less infiltration and higher surface runoff. The RMSE and TRMSE metrics are particularly sensitive to INFILT, indicating a key role in the generation and timing of high and low flows. This parameter has been identified as sensitive in all the studies listed in Table 1. DsMAX is the maximum velocity of baseflow, while $D s$ and $W s$ are the fraction of DSMAX and the fraction of the maximum soil moisture content in the third layer, respectively, where non-linear baseflow occurs. These three parameters are involved in the ARNO formulation of subsurface runoff (Franchini and Pacciani, 1991; Todini, 1996), controlling the speed of baseflow release from the third soil layer (Liang et al., 1994) and, specifically, the non-linear part of the baseflow generation function. The sensitivity indices found for these parameters are consistent with the high sensitivity measures reported by Mendoza et al. (2015b), Melsen et al. (2016) and Wi et al. (2017).

The Expt2 parameter is an exponent of the Brooks-Corey relationship (Brooks and Corey, 1964) and controls the hydraulic conductivity between the second and third soil layers. A small value for the Expt2 parameter increases inter-layer drainage for the same soil moisture content, and therefore increases baseflow generation. The Depth2 parameter is the thickness of the second soil layer. In general, thicker soil layers slow seasonal peak flows and increase water loss due to evapotranspiration (Xie et al., 2007). It should be noted that the parameter Depth2 has been identified as highly sensitive by many authors (Demaria et al., 2007; Mendoza et al., 2015b; Wi et al., 2017; Gou et al., 2020; Lilhare et al., 2020; Yeste et al., 2020; Melsen and Guse, 2021). Finally, Depth3 is the thickness of the third layer of soil, and the large sensitivities obtained here agree with the results reported by Mendoza et al. (2015b) and Wi et al. (2017).

The results in Figure 6 show that Expt 2 and Depth 2 also provide large sensitivities for metrics focused on evaporative fluxes (i.e., RR and TRANSP). Other parameters that are relevant for these processes are $L A I$ and the minimum stomatal resistance (Rmin). Indeed, Chaney et al. (2015) reported high sensitivity of annual flow biases to variations in Rmin. LAI is a 
dimensionless quantity that characterizes intra-annual variations in plant canopies, and it is defined as the one-sided green leaf area per unit ground surface area. On the other hand, Rmin is one of the parameters that control canopy resistance when computing transpiration from each vegetation class, following the formulations proposed by Blondin (1991) and Ducoudré et al. (1993). Both $L A I$ and Rmin provide null sensitivities if the land cover type is bare ground; however, Rmin can also produce null sensitivities in vegetated grid cells.

315 Figure 6 reveals the large influence of hard-coded parameters on PeakSWE, SnowLegth and SUBL, in particular $N E W \_A L B$, $A L B \_T H A$ and $A L B \_A A$. The $N E W_{-} A L B$ parameter is the new snow surface albedo, which controls the reflection of solar radiation and, therefore, the energy exchange between the atmosphere, forest canopy and the surface layer of the snowpack (Andreadis et al., 2009). Additionally. The $A L B \_A A$ and $A L B \_T H A$ parameters represent the albedo decay in the accumulation and melting season in the snow albedo curve, respectively (USACE, 1956). These seasons are defined based on the absence or presence of liquid water in the surface snow cover. These results correspond well with the high sensitivities reported by Mendoza et al. (2015b) for these three hard-coded parameters. Finally, the snow surface roughness length ( $\left.z 0 \_S N O W\right)$ also affects sublimation rates across Andean subdomains.

\subsection{What drives parameter sensitivities across different hydroclimates?}

Figure 8 shows the Spearman rank correlation coefficient, $r_{s}$, between parameter sensitivities and a suite of climatic, topographic, land cover and soil-related grid cell attributes described in Table 2. The magnitude and sign of correlation quantifies how each sensitivity index varies with a given geophysical attribute. The results show that the magnitude of the correlation varies depending on the combination of metric and parameter, with the maximum correlations generally found for soil parameters, such as DsMAX and $W s$ with precipitation $\left(r_{s}=0.91\right)$ and aridity index $\left(r_{s}=-0.91\right)$ for the FMS function (flashiness of the flow). For this example, the simulation of flow flashiness is highly sensitive to DsMAX and $W s$ in the wet region but insensitive in the arid area. Conversely, the minimum correlations are found for snow parameters. It should be noted that weak correlation indicates that there is less spatial pattern in sensitivity; however, the magnitude of sensitivity index can be high or low. For example, $N E W_{-} A L B$ is a highly sensitive parameter across the domain (Figure 6).

The results in Figure 8 also indicate that high correlations (either positive or negative) are mainly associated with climate indices, which exert a stronger influence compared to the remaining attribute classes. These strong dependencies of the parametric sensitivity on climate variables are somewhat expected, because some combinations of hydrological signatures and parameters inherit strong spatial climate patterns (Addor et al. 2018); compare, for example, aridity index Figure 1(d) with panel DsMAX - FMS; RMSE in Figure 7. Among climate descriptors, the aridity index, mean annual precipitation and relative humidity yield the highest correlations, and temperature exhibits a relatively lower influence on parametric sensitivity; this result that was confirmed with additional correlation analyses including only grid cells with mean annual temperatures below $3405^{\circ} \mathrm{C}$ and $2^{\circ} \mathrm{C}$ (not shown). The lowest correlations are obtained for mean slope (topographic attribute), shrub fraction (land cover attribute) and mean clay content of soil (soil attribute). The key influence of climatic conditions on hydrological 
behaviour is not new, since aridity is commonly regarded as the main driver of water partitioning at the land surface (Budyko, 1974; Hrachowitz et al., 2013).

Figure 8 shows that the extent to which parametric sensitivities are related to grid cell attributes depends on the target evaluation metric (i.e., runoff, evaporative processes and snow processes), with the three distinct groups containing the same influential parameters. In the following subsections, we discuss the results based on these groups, with emphasis on spatial patterns and process interpretation across our study basins. Table 6 summarizes, for each evaluation metric (i.e., physical process to be represented) and climatic zone (using the classification from Table 5), the three most important parameters. Hence, the lists contained therein can be used to guide the selection of parameters for hydrologic model calibration, based on the hydroclimatic regime and target process that modelers would like to represent.

\subsubsection{Runoff-oriented metrics}

The results presented in Figure 7 (see RMSE and TRMSE) and Figure 8 (RMSE) show a direct relationship between the sensitivities provided by INFILT, and the degree of aridity, especially in semi-arid to hyper-arid subdomains. The runofforiented metrics are also sensitive to baseflow generation parameters $D s, W s$ and $D S M A X$ in most basins - with a similar spatial distribution of $I S_{j}^{L}$ values -, excepting those located in the north and some areas in Southern Patagonia, where climatic conditions are arid or hyper-arid. In basins located in the extreme north, small sensitivities can be attributed to local climate characteristics: most precipitation events in that area occur in summer (i.e., December-March) due to orographic rains caused by air masses coming from the Amazon region, and there is usually little recharge to the aquifers. Additionally, the third soil layer in these basins generally does not reach saturation; therefore, runoff simulations in those areas are insensitive to variations in $D s$ and $W s$ because the non-linear part of the baseflow function is only activated when the moisture storage in the third layer exceeds a threshold (Gou et al., 2020). Because of the dependency of DsMAX with precipitation, this parameter could be playing a key role in baseflow generation processes over Andean regions (Figure 7). Finally, a similar spatial distribution of integrated first-order sensitivities for $D s, W s$ and $D S M A X$ is expected, since they all focus on baseflow generation (see panels DsMAX - FMS, RMSE -; Ws -TRMSE, FMS-; Ds -TRMSE- in Figure 7).

365 Expt2 is identified as sensitive for runoff-oriented metrics in basins with semi-arid to hyper-arid climates, characterized by small annual precipitation amounts and permanent water stress. In these hydroclimatic regimes, there is usually not enough water to reach the third soil layer, so water is stored in the second layer and drainage is mainly controlled by Expt2, affecting the vertical redistribution of soil moisture (FMS) and low flows (TRMSE), as shown in Figure 7. Depth2 provides large runoff sensitivities in dry-subhumid to hyper-arid hydroclimatic regimes, for the same reasons as Expt2. Variations in the depth of the second soil layer change the soil moisture of the layer, and higher (lower) values of Depth2 for the same volumetric water content produce lower (higher) soil moisture, affecting drainage between soil layers.

Finally, Depth3 provides large sensitivities for all runoff-oriented metrics, with similar spatial patterns to Ws, Ds and DsMAX, but to a smaller degree (Figure 7). Depth3 is particularly sensitive in humid-subhumid and humid catchments, suggesting a direct relationship with mean annual precipitation, or with the size and intermittency of storms (Abdulla and Lettenmaier, 
1997). In these climatic domains, periodic heavy rainfall events enable a continuous recharge of the second and third soil layers - which may reach saturation- and thus a constant baseflow generation that affects runoff response and the retention time of soil moisture, producing higher baseflow during wet seasons (Shi et al., 2008).

\subsubsection{Evaporative processes}

The evaluation metrics associated with these processes are RR (a measure of the overall water balance) and TRANSP (plant transpiration), being LAI, Rmin, Expt2 and Depth2 the most important parameters.

Figure 7 shows a pronounced spatial variability in $L A I$ sensitivities across a large domain that comprises very different land cover types. One can note that $L A I$ yields high sensitivities for nearly all hydroclimatic regimes, since this parameter controls the evaporation from the canopy layer and canopy transpiration. In hyper-arid climates, the $L A I$ is usually less important, given the permanent water stress common for grid cells with bare soil. In summary, $L A I$ is influential wherever vegetation exists, regardless of the prevailing hydroclimatic regime.

The parameter Rmin yields parametric sensitivities across humid/sub-humid and humid areas (Figure 7 and Table 6). In the canopy resistance process, there is a stomatal resistance multiplier, $\mathrm{g}_{\mathrm{sm}}[\mathrm{n}]$, defined as a soil moisture stress factor that depends on the water in the root zone for the $n$-th surface cover class. Thus, when the soil moisture in layer $n$ is less than the fraction of the moisture content at the wilting point, the value of $\mathrm{g}_{\mathrm{sm}}[\mathrm{n}]$ is 0 , while when the soil moisture is greater than the fractional content of soil moisture at the critical point ( $70 \%$ of field capacity), the value of $\mathrm{g}_{\mathrm{sm}}[\mathrm{n}]$ is 1 . For the intermediate condition, $\mathrm{g}_{\mathrm{sm}}[\mathrm{n}]$ values vary linearly with soil moisture in that layer, which explains why Rmin provides high sensitivities in very humid (i.e., large precipitation) climates.

Finally, our results show that Expt2 and Depth2 yield large sensitivities to RR and TRANSP in all hydroclimatic regimes, since they affect the soil moisture content in layer 2 , which indirectly affects the $g_{s m}[n]$ factor in the canopy resistance formulation. These parameters show a lower relative sensitivity in humid/sub-humid and humid climates, since the Rmin parameter becomes more relevant when there is no soil moisture stress (i.e., $\mathrm{g}_{\mathrm{sm}}[\mathrm{n}] \sim 1$ ).

\subsubsection{Snow processes}

Figure 7 shows that $N E W_{-} A L B, A L B_{-} T H A$ and $A L B \_A A$ yield high sensitivities throughout the study domain, especially in areas where snow processes dominate hydrological responses. In particular, the $N E W \_A L B$ parameter is important throughout the domain and reaches the highest values for snow-oriented evaluation metrics. Additionally, the results in Figure 7 show that $A L B \_A A$ and $A L B \_T H A$ dominate snow responses in different domains: the $A L B \_T H A$ parameter yields large sensitivities in humid and sub-humid mountain areas located southern from $34^{\circ} \mathrm{S}$, with large effects on the snow season length and the maximum SWE accumulation, while $A L B \_A A$ shows greater sensitivity for the other climatic regimes, affecting SnowLength and sublimation in semiarid, colder environments in Northern Chile $\left(26^{\circ}-29^{\circ} \mathrm{S}\right)$. 


\section{Conclusions}

In this study, we have re-visited parameter sensitivities in the Variable Infiltration Capacity hydrological model. To this end, we have implemented the DELSA method at every $0.05^{\circ} \times 0.05^{\circ}(\sim 5 \mathrm{~km})$ grid cell contained in 101 basins across continental Chile (i.e., a total of 5,574 grid cells), spanning a broad diversity of hydroclimatic (from hyper-arid to humid) and physiographic (e.g., topography, land cover) conditions. Our experiments consider a suite of 43 parameters included in soil, vegetation and snow process representations, with three of these corresponding to hard-coded parameters (i.e., not exposed to model users). We use eight model evaluation metrics that account for runoff components, evapotranspiration and snow processes, and conduct correlation analyses to disentangle relationships between parametric sensitivities and pixel-scale attributes. The main findings of this study are as follows:

- 31 out of 43 (i.e., $72 \%$ ) parameters yield little or no sensitivity, most of which correspond to soil and vegetation processes. Therefore, calibrating such parameters will lead to minimal improvements in system representations with considerable computational costs.

- The three model evaluation metrics focused on snow accumulation and ablation processes were found to be highly sensitive to hard-coded parameters. Exposing these parameters will certainly expand our abilities to perform extensive analysis and increase our opportunities to improve model fidelity and characterize model uncertainty.

- For some evaluation metrics, the climate attributes examined here are highly correlated with parameter sensitivities, which therefore inherit spatial patterns observed in climate variables across the territory. In particular, mean annual precipitation and the aridity index are highly correlated with $D s, W s$ and $D s M A X$ sensitivities when examining RMSE, TRMSE and FMS. Unexpectedly, temperature yields a relatively lower influence among climates descriptors, even for metrics and parameters associated with snow processes. The rest of the attributes (topographic, soil and land cover) provided generally low correlations, and therefore small predictive power on parameter sensitivities.

- Parametric sensitivities are strongly related with the climate types in the case study basins. In humid environments, the most important parameters are related to the third soil layer (Ws; Ds;DsMAX and Depth3) and vegetation (Rmin); in arid regimes, the most influential parameters are associated with the firsts soil layers (INFILT; Expt2; and Depth2).

- In snow-dominated areas, the hard-coded parameters $N E W_{-} A L B ; A L B \_T H A$ and $A L B \_A A$ provide large sensitivities to maximum SWE, snow season length and sublimation.

- The leaf area index $(L A I)$ is a crucial parameter wherever there is vegetation on the ground, especially if it presents an overstory. Although such condition is more frequent in humid environments, the relevance of this parameter depends on vegetation characteristics rather than the underlying climatic conditions.

Overall, our study contributes to the existing literature by providing guidance on relevant VIC parameters for a suite of target processes and climate types, using a large number of modelling units at a relatively high $(\sim 5 \mathrm{~km})$ spatial resolution. Future studies aiming at improving spatial calibration density and/or parameter regionalization techniques using VIC - or any similar hydrology or land surface model - could incorporate this information to define spatially varying target parameters, and examine 
to what extent the spatial patterns in parameter sensitivities relate to calibrated parameter fields. Finally, the strong correlations found here between parameter sensitivities and hydroclimatic properties reaffirm the need to incorporate periods with contrasting climate characteristics in sensitivity analysis and calibration strategies in order to achieve more credible hydrologic model simulations under changing climatic conditions.

\section{Data availability}

Land cover descriptors for all grid cells and reference VIC model outputs used to compute performance metrics were obtained from the National Water Balance database (DGA, 2018, 2019, 2020). This information may be requested through the website

445 https://siac.mop.gob.cl/. Other grid cell attributes were obtained from the United States Geological Survey dataset (https://earthexplorer.usgs.gov/), the CR2met dataset (https://www.cr2.cl/), and SoilGrids250m 2.0 (https://soilgrids.org/). Catchment scale hydrometeorological data were obtained from the CAMELS-CL dataset (Alvarez-Garreton et al., 2018).

\section{Author contributions}

All the authors were involved in the conceptualization of this study. US and PM designed the methodology and analysis 450 framework and drafted the paper. US configured the VIC model, conducted simulations, analysed the results and created all the figures. AN and NM provided insights into the sensitivity analysis results. All the authors discussed the results and contributed to writing, reviewing and editing the manuscript.

\section{Competing interests}

The authors declare that they have no conflict of interest.

\section{Acknowledgments}

Pablo A. Mendoza received support from Fondecyt Project 11200142 and CONICYT/PIA Project AFB180004. This research was partially supported by the supercomputing infrastructure of the NLHPC (ECM-02). The National Center for Atmospheric Research is a major facility sponsored by the National Science Foundation under Cooperative Agreement No. 1852977. We thank Eduardo Muñoz-Castro and Nicolás Vásquez for their advice and assistance in setting up model simulations, and Ximena Vargas and Miguel Lagos for their suggestions on earlier versions of this manuscript.

\section{References}

Abbaspour, K. C., Rouholahnejad, E., Vaghefi, S., Srinivasan, R., Yang, H. and Kløve, B.: A continental-scale hydrology and 
https://doi.org/10.5194/hess-2021-550

Preprint. Discussion started: 22 November 2021

(c) Author(s) 2021. CC BY 4.0 License.
Hydrology and

Earth System

Sciences

Discussions

water quality model for Europe: Calibration and uncertainty of a high-resolution large-scale SWAT model, J. Hydrol., 524, 733-752, doi:10.1016/j.jhydrol.2015.03.027, 2015.

Abdulla, F. A. and Lettenmaier, D. P.: Development of regional parameter estimation equations for a macroscale hydrologic model, J. Hydrol., 197(1-4), 230-257, doi:10.1016/S0022-1694(96)03262-3, 1997.

Addor, N. and Melsen, L. A.: Legacy, Rather Than Adequacy, Drives the Selection of Hydrological Models, Water Resour. Res., 55(1), 378-390, doi:10.1029/2018WR022958, 2019.

Addor, N., Nearing, G., Prieto, C., Newman, A. J., Le Vine, N. and Clark, M. P.: A Ranking of Hydrological Signatures Based on Their Predictability in Space, Water Resour. Res., 54(11), 8792-8812, doi:10.1029/2018WR022606, 2018.

Alvarez-Garreton, C., Mendoza, P. A., Boisier, J. P., Addor, N., Galleguillos, M., Zambrano-Bigiarini, M., Lara, A., Puelma, C., Cortes, G., Garreaud, R., McPhee, J. and Ayala, A.: The CAMELS-CL dataset: catchment attributes and meteorology for large sample studies - Chile dataset, Hydrol. Earth Syst. Sci., 22(11), 5817-5846, doi:10.5194/hess-22-5817-2018, 2018.

Andreadis, K. M., Storck, P. and Lettenmaier, D. P.: Modeling snow accumulation and ablation processes in forested environments, Water Resour. Res., 45, W05429, doi:10.1029/2008WR007042, 2009.

Arheimer, B., Pimentel, R., Isberg, K., Crochemore, L., Andersson, J. C. M., Hasan, A. and Pineda, L.: Global catchment modelling using World-Wide HYPE (WWH), open data, and stepwise parameter estimation, Hydrol. Earth Syst. Sci., 24(2), 535-559, doi:10.5194/hess-24-535-2020, 2020.

Bastidas, L. A., Gupta, H. V, Sorooshian, S., Shuttleworth, W. J. and Yang, Z. L.: Sensitivity analysis of a land surface scheme using multicriteria methods, J. Geophys. Res., 104, 19,481-19,490, 1999.

Bastidas, L. A., Hogue, T. S., Sorooshian, S., Gupta, H. V. and Shuttleworth, W. J.: Parameter sensitivity analysis for different complexity land surface models using multicriteria methods, J. Geophys. Res., 111, D20101, doi:10.1029/2005JD006377, 2006.

Beck, H. E., van Dijk, A. I. J. M., de Roo, A., Miralles, D. G., McVicar, T. R., Schellekens, J. and Bruijnzeel, L. A.: Globalscale regionalization of hydrologic model parameters, Water Resour. Res., 52(5), 3599-3622, doi:10.1002/2015WR018247, 2016.

Bennett, K. E., Urrego Blanco, J. R., Jonko, A., Bohn, T. J., Atchley, A. L., Urban, N. M. and Middleton, R. S.: Global Sensitivity of Simulated Water Balance Indicators Under Future Climate Change in the Colorado Basin, Water Resour. Res., 54(1), 132-149, doi:10.1002/2017WR020471, 2018.

490 Berg, P., Donnelly, C. and Gustafsson, D.: Near-real-time adjusted reanalysis forcing data for hydrology, Hydrol. Earth Syst. Sci., 22(2), 989-1000, doi:10.5194/hess-22-989-2018, 2018.

Blondin, C.: Parameterization of Land-Surface Processes in Numerical Weather Prediction, L. Surf. Evaporation, 31-54, doi:10.1007/978-1-4612-3032-8_3, 1991.

Bohn, T. J. and Vivoni, E. R.: Process-based characterization of evapotranspiration sources over the North American monsoon region, Water Resour. Res., 52(1), 358-384, doi:10.1002/2015WR017934, 2016.

Brooks, R. and Corey, A.: Hydraulic properties of porous media, Hydrol. Pap. Color. State Univ., 3(March), 37 pp, 1964. 
Budyko, M. I.: Climate and Life., 1974.

C3S and Copernicus Climate Change Service (C3S): ERA5: Fifth generation of ECMWF atmospheric reanalyses of the global climate, C3S [online] Available from: https://cds.climate.copernicus.eu/cdsapp\#!/home (Accessed 20 January 2018), 2017.

Casper, M. C., Grigoryan, G., Gronz, O., Gutjahr, O., Heinemann, G., Ley, R. and Rock, A.: Analysis of projected hydrological behavior of catchments based on signature indices, Hydrol. Earth Syst. Sci., 16(2), 409-421, doi:10.5194/hess-16-409-2012, 2012.

Chaney, N. W., Herman, J. D., Reed, P. M. and Wood, E. F.: Flood and drought hydrologic monitoring: The role of model parameter uncertainty, Hydrol. Earth Syst. Sci., 19(7), 3239-3251, doi:10.5194/hess-19-3239-2015, 2015.

Chawla, I. and Mujumdar, P. P.: Isolating the impacts of land use and climate change on streamflow, Hydrol. Earth Syst. Sci., 19(8), 3633-3651, doi:10.5194/hess-19-3633-2015, 2015.

Chegwidden, O. S. S., Nijssen, B., Rupp, D. E. E., Arnold, J. R. R., Clark, M. P. P., Hamman, J. J. J., Kao, S. C. S. C., Mao, Y., Mizukami, N., Mote, P. W., Pan, M., Pytlak, E. and Xiao, M.: How do modeling decisions affect the spread among hydrologic climate change projections? Exploring a large ensemble of simulations across a diversity of hydroclimates, Earth's Futur., 7(6), 623-637, doi:10.1029/2018EF001047, 2019.

Chen, F., Barlage, M., Tewari, M., Rasmussen, R., Jin, J., Lettenmaier, D., Livneh, B., Lin, C., Miguez-Macho, G., Niu, G., Wen, L. and Yang, Z.: Modeling seasonal snowpack evolution in the complex terrain and forested Colorado Headwaters region: A model intercomparison study, J. Geophys. Res. Atmos., 119(24), 13,795-13,819, doi:10.1002/2014JD022167, 2014. Cherkauer, K. A., Bowling, L. C. and Lettenmaier, D. P.: Variable infiltration capacity cold land process model updates, Glob. Planet. Change, 38(1-2), 151-159, doi:10.1016/S0921-8181(03)00025-0, 2003.

Chipman, H. A., George, E. I. and McCulloch, R. E.: BART: Bayesian additive regression trees, Ann. Appl. Stat., 4(1), 266298, doi:10.1214/09-AOAS285, 2010.

Clark, M. P., Nijssen, B., Lundquist, J. D., Kavetski, D., Rupp, D. E., Woods, R. A., Freer, J. E., Gutmann, E. D., Wood, A. W., Brekke, L. D., Arnold, J. R., Gochis, D. J. and Rasmussen, R. M.: A unified approach for process-based hydrologic modeling: 1. Modeling concept, Water Resour. Res., doi:10.1002/2015WR017198, 2015.

Clark, M. P., Bierkens, M. F. P., Samaniego, L., Woods, R. A., Uijlenhoet, R., Bennett, K. E., Pauwels, V. R. N., Cai, X., Wood, A. W. and Peters-Lidard, C. D.: The evolution of process-based hydrologic models: historical challenges and the collective quest for physical realism, Hydrol. Earth Syst. Sci., 21(7), 3427-3440, doi:10.5194/hess-21-3427-2017, 2017.

Cosby, B. J., Hornberger, G. M., Clapp, R. B. and Ginn, T. R.: A Statistical Exploration of the Relationships of Soil Moisture Characteristics to the Physical Properties of Soils, Water Resour. Res., 20(6), 682-690, doi:10.1029/WR020i006p00682, 1984. Cuntz, M., Mai, J., Samaniego, L., Clark, M., Wulfmeyer, V., Branch, O., Attinger, S. and Thober, S.: The impact of standard and hard-coded parameters on the hydrologic fluxes in the Noah-MP land surface model, J. Geophys. Res. Atmos., 121(18), 10,676-10,700, doi:10.1002/2016JD025097, 2016.

DeChant, C. M. and Moradkhani, H.: Toward a reliable prediction of seasonal forecast uncertainty: Addressing model and initial condition uncertainty with ensemble data assimilation and Sequential Bayesian Combination, J. Hydrol., 519, 2967- 
2977, doi:10.1016/j.jhydrol.2014.05.045, 2014.

Dee, D. P., Uppala, S. M., Simmons, A. J., Berrisford, P., Poli, P., Kobayashi, S., Andrae, U., Balmaseda, M. A., Balsamo, G., Bauer, P., Bechtold, P., Beljaars, A. C. M., van de Berg, L., Bidlot, J., Bormann, N., Delsol, C., Dragani, R., Fuentes, M., Geer, A. J., Haimberger, L., Healy, S. B., Hersbach, H., Hólm, E. V., Isaksen, L., Kållberg, P., Köhler, M., Matricardi, M., Mcnally, A. P., Monge-Sanz, B. M., Morcrette, J. J., Park, B. K., Peubey, C., de Rosnay, P., Tavolato, C., Thépaut, J. N. and Vitart, F.: The ERA-Interim reanalysis: Configuration and performance of the data assimilation system, Q. J. R. Meteorol. Soc., 137(656), 553-597, doi:10.1002/qj.828, 2011.

Demaria, E. M., Nijssen, B. and Wagener, T.: Monte Carlo sensitivity analysis of land surface parameters using the Variable Infiltration Capacity model, J. Geophys. Res., 112(D11), 1-15, doi:10.1029/2006JD007534, 2007.

540 DGA: Actualización del Balance Hídrico Nacional, SIT N 417., 2017 a.

DGA: Metodología para la Actualización del Balance Hídrico Nacional., $2017 \mathrm{~b}$.

DGA: Aplicación de la metodología de actualización del balance hídrico nacional a las macrozonas Norte y Centro, SIT N ${ }^{\circ}$ 435., 2018.

DGA: Aplicación de La Metodología de Actualización del Balance Hídrico Nacional en las Cuencas de la Macrozona Sur y

545 Parte de la Macrozona Austral., 2019.

DGA: Aplicación de la metodología de actualización del balance hídrico nacional en las cuencas de la parte sur de la Macrozona Austral e Isla de Pascua, SIT N 444., 2020.

Do, H. X., Gudmundsson, L., Leonard, M. and Westra, S.: The Global Streamflow Indices and Metadata Archive (GSIM)-Part 1: The production of a daily streamflow archive and metadata, Earth Syst. Sci. Data, 10(2), 765-785, doi:10.5194/essd-10$550 \quad 765-2018,2018$.

Dorman, J. and Sellers, P.: A global climatology of albedo, roughness length and stomatal resistance for atmospheric general circulation models as represented by the simple biosphere model (SiB), J. Appl. Meteorol., 28, 833-855, 1989.

Ducoudré, N. I., Laval, K. and Perrier, A.: SECHIBA, a New Set of Parameterizations of the Hydrologic Exchanges at the Land-Atmosphere Interface within the LMD Atmospheric General Circulation Model, J. Clim., 6(2), 248-273, doi:10.1175/1520-0442(1993)006<0248:sansop>2.0.co;2, 1993.

Fang, H., Wei, S., Jiang, C. and Scipal, K.: Theoretical uncertainty analysis of global MODIS, CYCLOPES, and GLOBCARBON LAI products using a triple collocation method, Remote Sens. Environ., 124, 610-621, doi:10.1016/j.rse.2012.06.013, 2012.

Fang, H., Jiang, C., Li, W., Wei, S., Baret, F., Chen, J. M., Garcia-Haro, J., Liang, S., Liu, R., Myneni, R. B., Pinty, B., Xiao, 560 Z. and Zhu, Z.: Characterization and intercomparison of global moderate resolution leaf area index (LAI) products: Analysis of climatologies and theoretical uncertainties, J. Geophys. Res. Biogeosciences, 118(2), 529-548, doi:10.1002/jgrg.20051, 2013.

Foglia, L., Hill, M. C., Mehl, S. W. and Burlando, P.: Sensitivity analysis, calibration, and testing of a distributed hydrological model using error-based weighting and one objective function, Water Resour. Res., 45(6), W06427, 
doi:10.1029/2008WR007255, 2009.

Franchini, M. and Pacciani, M.: Comparative analysis of several conceptual rainfall-runoff models, J. Hydrol., 122(1-4), 161219, doi:10.1016/0022-1694(91)90178-K, 1991.

Friedman, J. H.: Multivariate Adaptive Regression Splines, Ann. Stat., 19(1), 590-606, doi:10.1214/aos/1176347963, 1991. Gates, D. M. and Evans, L. T.: Environmental Control of Plant Growth., Bull. Torrey Bot. Club, 91(3), 235, doi:10.2307/2483533, 1964.

Gharari, S., Clark, M. P., Mizukami, N., Wong, J. S., Pietroniro, A. and Wheater, H. S.: Improving the representation of subsurface water movement in land models, J. Hydrometeorol., 20(12), 2401-2418, doi:10.1175/JHM-D-19-0108.1, 2019.

Ghiggi, G., Humphrey, V., Seneviratne, S. and Gudmundsson, L.: GRUN: An observations-based global gridded runoff dataset from 1902 to 2014, GRUN An Obs. Glob. gridded runoff dataset from 1902 to 2014, 1-32, doi:10.5194/essd-2019-32, 2019.

Göhler, M., Mai, J. and Cuntz, M.: Use of eigendecomposition in a parameter sensitivity analysis of the Community Land Model, J. Geophys. Res. Biogeosciences, 118(2), 904-921, doi:10.1002/jgrg.20072, 2013.

Gou, J., Miao, C., Duan, Q., Tang, Q., Di, Z., Liao, W., Wu, J. and Zhou, R.: Sensitivity Analysis-Based Automatic Parameter Calibration of the VIC Model for Streamflow Simulations Over China, Water Resour. Res., 56(1), 1-19, doi:10.1029/2019WR025968, 2020.

580 Hamman, J. J., Nijssen, B., Bohn, T. J., Gergel, D. R. and Mao, Y.: The variable infiltration capacity model version 5 (VIC5): Infrastructure improvements for new applications and reproducibility, Geosci. Model Dev., 11(8), 3481-3496, doi:10.5194/gmd-11-3481-2018, 2018.

Hengl, T., De Jesus, J. M., Heuvelink, G. B. M., Gonzalez, M. R., Kilibarda, M., Blagotić, A., Shangguan, W., Wright, M. N., Geng, X., Bauer-Marschallinger, B., Guevara, M. A., Vargas, R., MacMillan, R. A., Batjes, N. H., Leenaars, J. G. B., Ribeiro,

585 E., Wheeler, I., Mantel, S. and Kempen, B.: SoilGrids250m: Global gridded soil information based on machine learning., 2017. Hogue, T. S., Bastidas, L., Gupta, H., Sorooshian, S., Mitchell, K. and Emmerich, W.: Evaluation and transferability of the Noah land surface model in semiarid environments, J. Hydrometeorol., 6(1), 68-84, 2005.

Hornberger, G M and Spear, R. C.: Approach to the preliminary analysis of environmental systems, J. Environ. Mgmt, 12:1, $7-18,1981$.

590 Hou, Z., Huang, M., Leung, L. R., Lin, G. and Ricciuto, D. M.: Sensitivity of surface flux simulations to hydrologic parameters based on an uncertainty quantification framework applied to the Community Land Model, J. Geophys. Res. Atmos., 117(15), 1-18, doi:10.1029/2012JD017521, 2012.

Hrachowitz, M., Savenije, H. H. G., Blöschl, G., McDonnell, J. J., Sivapalan, M., Pomeroy, J. W., Arheimer, B., Blume, T., Clark, M. P., Ehret, U., Fenicia, F., Freer, J. E., Gelfan, A., Gupta, H. V., Hughes, D. A., Hut, R. W., Montanari, A., Pande,

595 S., Tetzlaff, D., Troch, P. A., Uhlenbrook, S., Wagener, T., Winsemius, H. C., Woods, R. A., Zehe, E. and Cudennec, C.: A decade of Predictions in Ungauged Basins (PUB)-a review, Hydrol. Sci. J., doi:10.1080/02626667.2013.803183, 2013.

Huang, M. and Liang, X.: On the assessment of the impact of reducing parameters and identification of parameter uncertainties for a hydrologic model with applications to ungauged basins, J. Hydrol., 320(1-2), 37-61, doi:10.1016/j.jhydrol.2005.07.010, 
2006.

600 Lawrence, D. M., Fisher, R. A., Koven, C. D., Oleson, K. W., Swenson, S. C., Bonan, G., Collier, N., Ghimire, B., van Kampenhout, L., Kennedy, D., Kluzek, E., Lawrence, P. J., Li, F., Li, H., Lombardozzi, D., Riley, W. J., Sacks, W. J., Shi, M., Vertenstein, M., Wieder, W. R., Xu, C., Ali, A. A., Badger, A. M., Bisht, G., van den Broeke, M., Brunke, M. A., Burns, S. P., Buzan, J., Clark, M., Craig, A., Dahlin, K., Drewniak, B., Fisher, J. B., Flanner, M., Fox, A. M., Gentine, P., Hoffman, F., Keppel-Aleks, G., Knox, R., Kumar, S., Lenaerts, J., Leung, L. R., Lipscomb, W. H., Lu, Y., Pandey, A., Pelletier, J. D., Perket, J., Randerson, J. T., Ricciuto, D. M., Sanderson, B. M., Slater, A., Subin, Z. M., Tang, J., Thomas, R. Q., Val Martin, M. and Zeng, X.: The Community Land Model Version 5: Description of New Features, Benchmarking, and Impact of Forcing Uncertainty, J. Adv. Model. Earth Syst., 11(12), 4245-4287, doi:10.1029/2018MS001583, 2019.

Liang, X. and Guo, J.: Intercomparison of land-surface parameterization schemes: sensitivity of surface energy and water fluxes to model parameters, J. Hydrol., 279(1-4), 182-209, doi:10.1016/S0022-1694(03)00168-9, 2003.

Liang, X., Lettenmaier, D. P., Wood, E. F. and Burges, S. J.: A simple hydrologically based model of land surface water and energy fluxes for general circulation models, J. Geophys. Res., 99(D7), 14,415.14.428, doi:10.1029/94jd00483, 1994.

Liang, X., Wood, E. F. and Lettenmaier, D. P.: Surface soil moisture parameterization of the VIC-2L model: Evaluation and modification, Glob. Planet. Change, 13(1-4), 195-206, doi:10.1016/0921-8181(95)00046-1, 1996.

Lilhare, R., Pokorny, S., Déry, S. J., Stadnyk, T. A. and Koenig, K. A.: Sensitivity analysis and uncertainty assessment in

615 water budgets simulated by the variable infiltration capacity model for Canadian subarctic watersheds, Hydrol. Process., 34(9), 2057-2075, doi:10.1002/hyp.13711, 2020.

Marks, D. and Dozier, J.: Climate and Energy Exchange at the Snow Surface in the Alpine Region of the Sierra Nevada 2. Snow Cover Energy Balance, Water Resour. Res., 28(11), 3043-3054, 1992.

Massoud, E. C., Xu, C., Fisher, R. A., Knox, R. G., Walker, A. P., Serbin, S. P., Christoffersen, B. O., Holm, J. A., Kueppers, L. M., Ricciuto, D. M., Wei, L., Johnson, D. J., Chambers, J. Q., Koven, C. D., McDowell, N. G. and Vrugt, J. A.: Identification of key parameters controlling demographically structured vegetation dynamics in a land surface model: CLM4.5(FATES), Geosci. Model Dev., 12(9), 4133-4164, doi:10.5194/gmd-12-4133-2019, 2019.

McCabe, M. F., Rodell, M., Alsdorf, D. E., Miralles, D. G., Uijlenhoet, R., Wagner, W., Lucieer, A., Houborg, R., Verhoest, N. E. C., Franz, T. E., Shi, J., Gao, H. and Wood, E. F.: The future of Earth observation in hydrology, Hydrol. Earth Syst. Sci., 625 21(7), 3879-3914, doi:10.5194/hess-21-3879-2017, 2017.

Melsen, L., Teuling, A., Torfs, P., Zappa, M., Mizukami, N., Clark, M. and Uijlenhoet, R.: Representation of spatial and temporal variability in large-domain hydrological models: Case study for a mesoscale pre-Alpine basin, Hydrol. Earth Syst. Sci., 20(6), 2207-2226, doi:10.5194/hess-20-2207-2016, 2016.

Melsen, L. A. and Guse, B.: Climate change impacts model parameter sensitivity-implications for calibration strategy and model diagnostic evaluation, Hydrol. Earth Syst. Sci., 25(3), 1307-1332, doi:10.5194/hess-25-1307-2021, 2021.

Melsen, L. A., Teuling, A. J., Torfs, P. J. J. F., Zappa, M., Mizukami, N., Mendoza, P. A., Clark, M. P. and Uijlenhoet, R.: Subjective modeling decisions can significantly impact the simulation of flood and drought events, J. Hydrol., 568(November 
https://doi.org/10.5194/hess-2021-550

Preprint. Discussion started: 22 November 2021

(c) Author(s) 2021. CC BY 4.0 License.
Hydrology and

Earth System

Sciences

Discussions

2018), 1093-1104, doi:10.1016/j.jhydrol.2018.11.046, 2019.

Mendoza, P. A., Clark, M. P., Barlage, M., Rajagopalan, B., Samaniego, L., Abramowitz, G. and Gupta, H.: Are we

unnecessarily constraining the agility of complex process-based models?, Water Resour. Res., 51, doi:10.1002/2014WR015820, 2015a.

Mendoza, P. A., Clark, M. P., Mizukami, N., Newman, A., Barlage, M., Gutmann, E., Rasmussen, R., Rajagopalan, B., Brekke, L. and Arnold, J.: Effects of hydrologic model choice and calibration on the portrayal of climate change impacts, J. Hydrometeorol., 16(2), 762-780, doi:10.1175/JHM-D-14-0104.1, 2015b.

640 Misirli, F., Gupta, H. V, Sorooshian, S. and Thiemann, M.: Bayesian recursive estimation of parameter and output uncertainty for watershed models, vol. 6, edited by Q. Duan, H. V. Gupta, S. Sorooshian, A. N. Rousseau, and R. Turcotte, pp. 113-124, American Geophysical Union, Washington, D. C., 2003.

Mitchell, K. E., Lohmann, D., Houser, P. R., Wood, E. F., Schaake, J. C., Robock, A., Cosgrove, B. A., Sheffield, J., Duan, Q., Luo, L., Higgins, W., Pinker, R. T., Tarpley, J. D., Lettenmaier, D. P., Marshall, C. H., Entin, J. K., Pan, M., Shi, W.,

645 Koren, V., Meng, J., Ramsay, B. H. and Bailey, A. A.: The multi-institution North American Land Data Assimilation System (NLDAS): Utilizing multiple GCIP products and partners in a continental distributed hydrological modeling system, J. Geophys. Res., 109(D7), D07S90, doi:10.1029/2003JD003823, 2004.

Mizukami, N., P. Clark, M., G. Slater, A., D. Brekke, L., M. Elsner, M., R. Arnold, J., Gangopadhyay, S., Clark, M. P., Slater, A. G., Brekke, L. D., Elsner, M. M., Arnold, J. R., Gangopadhyay, S., P. Clark, M., G. Slater, A., D. Brekke, L., M. Elsner,

M. and R. Arnold, J.: Hydrologic Implications of Different Large-Scale Meteorological Model Forcing Datasets in Mountainous Regions, J. Hydrometeorol., 15(1), 474-488, doi:10.1175/JHM-D-13-036.1, 2014.

Mizukami, N., Clark, M. P., Gutmann, E. D., Mendoza, P. A., Newman, A. J., Nijssen, B., Livneh, B., Hay, L. E., Arnold, J. R. and Brekke, L. D.: Implications of the Methodological Choices for Hydrologic Portrayals of Climate Change over the Contiguous United States: Statistically Downscaled Forcing Data and Hydrologic Models, J. Hydrometeorol., 17(1), 73-98, doi:10.1175/JHM-D-14-0187.1, 2016.

Montgomery, D. C.: Design and analysis of experiments, Wiley., 1991.

Morris, M. D.: Factorial sampling plans for preliminary computational experiments, Technometrics, 33(2), 161-174, doi:10.1080/00401706.1991.10484804, 1991.

Myneni, R. B., Ramakrishna, R., Nemani, R. and Running, S. W.: Estimation of global leaf area index and absorbed par using radiative transfer models, IEEE Trans. Geosci. Remote Sens., 35(6), 1380-1393, doi:10.1109/36.649788, 1997.

Al Nakshabandi, G. and Kohnke, H.: Thermal conductivity and diffusivity of soils as related to moisture tension and other physical properties, Agric. Meteorol., 2(4), 271-279, doi:10.1016/0002-1571(65)90013-0, 1965.

Nash, J. and Sutcliffe, J.: River flow forecasting through conceptual models part I - A discussion of principles, J. Hydrol., 10(3), 282-290, doi:10.1016/0022-1694(70)90255-6, 1970.

665 Niu, G.-Y., Yang, Z.-L., Mitchell, K. E., Chen, F., Ek, M. B., Barlage, M., Kumar, A., Manning, K., Niyogi, D., Rosero, E., Tewari, M. and Xia, Y.: The community Noah land surface model with multiparameterization options (Noah-MP): 1. Model 
description and evaluation with local-scale measurements, J. Geophys. Res., 116(D12), D12109, doi:10.1029/2010JD015139, 2011.

Pablo Boisier, J., Alvarez-Garretón, C., Cepeda, J., Osses, A., Vásquez, N. and Rondanelli, R.: CR2MET: A high-resolution precipitation and temperature dataset for hydroclimatic research in Chile., 2018.

Pi, H. and Peterson, C.: Finding the Embedding Dimension and Variable Dependencies in Time Series, Neural Comput., 6(3), 509-520, doi:10.1162/neco.1994.6.3.509, 1994.

Pokhrel, P. and Gupta, H. V.: On the use of spatial regularization strategies to improve calibration of distributed watershed models, Water Resour. Res., 46(1), W01505, doi:10.1029/2009WR008066, 2010.

Prihodko, L., Denning, A. S. S., Hanan, N. P. P., Baker, I. and Davis, K.: Sensitivity, uncertainty and time dependence of parameters in a complex land surface model, Agric. For. Meteorol., 148(2), 268-287, doi:10.1016/j.agrformet.2007.08.006, 2008.

Rakovec, O., Hill, M. C., Clark, M. P., Weerts, A. H., Teuling, A. J. and Uijlenhoet, R.: Distributed Evaluation of Local Sensitivity Analysis (DELSA), with application to hydrologic models, Water Resour. Res., 50, 1-18, doi:10.1002/2013WR014063, 2014.

Rawls, W. J.; Ahuja, L. R.; Brakensiek, D. L.; Shirmohammadi, A.: Infiltration and soil water movement, in Handbook of hydrology, edited by D. R. Maidment, p. pp.5.1-5.51, McGraw-Hill Inc., New York., 1992.

Razavi, S. and Gupta, H. V.: What do we mean by sensitivity analysis? The need for comprehensive characterization of "global" sensitivity in Earth and Environmental systems models, Water Resour. Res., 51(5), 3070-3092, doi:10.1002/2014WR016527, 2015.

Razavi, S. and Gupta, H. V.: A new framework for comprehensive, robust, and efficient global sensitivity analysis: 2. Application, Water Resour. Res., 52(1), 423-439, doi:10.1002/2015WR017558, 2016.

Reba, M. L., Marks, D., Link, T. E., Pomeroy, J. and Winstral, A.: Sensitivity of model parameterizations for simulated latent heat flux at the snow surface for complex mountain sites, Hydrol. Process., 28(3), 868-881, doi:10.1002/hyp.9619, 2014.

Reynolds, C. A., Jackson, T. J. and Rawls, W. J.: Estimating soil water-holding capacities by linking the Food and Agriculture Organization soil map of the world with global pedon databases and continuous pedotransfer functions, Water Resour. Res., 36(12), 3653-3662, doi:10.1029/2000WR900130, 2000.

Rosero, E., Yang, Z.-L., Wagener, T., Gulden, L. E., Yatheendradas, S. and Niu, G.-Y.: Quantifying parameter sensitivity, interaction, and transferability in hydrologically enhanced versions of the Noah land surface model over transition zones during the warm season, J. Geophys. Res., 115(D3), 1-21, doi:10.1029/2009JD012035, 2010.

Rosolem, R., Gupta, H. V., Shuttleworth, W. J., Zeng, X. and de Gonçalves, L. G. G.: A fully multiple-criteria implementation of the Sobol' method for parameter sensitivity analysis, J. Geophys. Res., 117(D7), 1-18, doi:10.1029/2011JD016355, 2012. Saltelli, A., Ratto, M., Andres, T., Campolongo, F., Cariboni, J., Gatelli, D., Saisana, M. and Tarantola, S.: Global Sensitivity Analysis. The Primer., 2008.

700 Schmied, H. M., Eisner, S., Franz, D., Wattenbach, M., Portmann, F. T., Flörke, M. and Döll, P.: Sensitivity of simulated 
global-scale freshwater fluxes and storages to input data, hydrological model structure, human water use and calibration, Hydrol. Earth Syst. Sci., 18(9), 3511-3538, doi:10.5194/hess-18-3511-2014, 2014.

Sheikholeslami, R., Gharari, S., Papalexiou, S. M. and Clark, M. P.: VISCOUS: A Variance-Based Sensitivity Analysis Using Copulas for Efficient Identification of Dominant Hydrological Processes, Water Resour. Res., 1-24, doi:10.1029/2020wr028435, 2021.

Shi, X., Wood, A. W. and Lettenmaier, D. P.: How essentialis hydrologic model calibration to seasonal stream flow forecasting?, J. Hydrometeorol., 9(6), 1350-1363, doi:10.1175/2008JHM1001.1, 2008.

Sobol', I. M.: Global sensitivity indices for nonlinear mathematical models and their Monte Carlo estimates, Math. Comput. Simul., 55, 271-280, 2001.

710 Sobol', I. M. and Kucherenko, S.: A new derivative based importance criterion for groups of variables and its link with the global sensitivity indices, Comput. Phys. Commun., 181(7), 1212-1217, doi:10.1016/j.cpc.2010.03.006, 2010.

Tang, G., Clark, M. P., Papalexiou, S. M., Newman, A. J., Wood, A. W., Brunet, D. and Whitfield, P. H.: Emdna: An ensemble meteorological dataset for north america, Earth Syst. Sci. Data, 13(7), 3337-3362, doi:10.5194/essd-13-3337-2021, 2021.

Tian, S., Tregoning, P., Renzullo, L. J., van Dijk, A. I. J. M., Walker, J. P., Pauwels, V. R. N. and Allgeyer, S.: Improved water

balance component estimates through joint assimilation of GRACE water storage and SMOS soil moisture retrievals, Water Resour. Res., 53(3), 1820-1840, doi:10.1002/2016WR019641, 2017.

Tian, Y., Woodcock, C. E., Wang, Y., Privette, J. L., Shabanov, N. V., Zhou, L., Zhang, Y., Buermann, W., Dong, J., Veikkanen, B., Häme, T., Andersson, K., Ozdogan, M., Knyazikhin, Y. and Myneni, R. B.: Multiscale analysis and validation of the MODIS LAI product I. Uncertainty assessment, Remote Sens. Environ., 83(3), 414-430, doi:10.1016/S00344257(02)00047-0, 2002.

Todini, E.: The ARNO rainfall-runoff model, J. Hydrol., 175, 339-382, 1996.

Tonkin, M. J. and Doherty, J.: A hybrid regularized inversion methodology for highly parameterized environmental models, Water Resour. Res., 41(10), 1-16, doi:10.1029/2005WR003995, 2005.

UNEP: World atlas of desertification.. ed. 2, edited by N. Middleton and D. Thomas, Arnold, Hodder Headline, PLC., 1997.

USACE: Snow hydrology: Summary report of the snow investigations, North Pacific Division, Corps of Engineers, U.S. Army., 1956.

Vano, J. A. and Lettenmaier, D. P.: A sensitivity-based approach to evaluating future changes in Colorado River discharge, Clim. Change, 122(4), 621-634, doi:10.1007/s10584-013-1023-x, 2014.

Vásquez, N., Cepeda, J., Gómez, T., Mendoza, P. A., Lagos, M., Boisier, J. P., Álvarez-Garretón, C. and Vargas, X.: 730 Catchment-Scale Natural Water Balance in Chile, in Water Resources of Chile, pp. 189-208., 2021.

Verbist, K., Santibañez, F., Gabriels, D. and Soto, G.: Documento Técnico № 25. Atlas de Zonas Áridas de América Latina y el Caribe., 2010.

Vořechovský, M.: Hierarchical Refinement of Latin Hypercube Samples, Comput. Civ. Infrastruct. Eng., 30(5), 394-411, doi:10.1111/mice.12088, 2015. 
https://doi.org/10.5194/hess-2021-550

Preprint. Discussion started: 22 November 2021

(C) Author(s) 2021. CC BY 4.0 License.
Hydrology and

Earth System

Sciences

Discussions

735 Wi, S., Ray, P., Demaria, E. M. C., Steinschneider, S. and Brown, C.: A user-friendly software package for VIC hydrologic model development, Environ. Model. Softw., 98, 35-53, doi:10.1016/j.envsoft.2017.09.006, 2017.

Wood, A. W., Kumar, A. and Lettenmaier, D. P.: A retrospective assessment of National Centers for Environmental prediction climate model-based ensemble hydrologic forecasting in the western United States, J. Geophys. Res. D Atmos., 110(4), 1-16, doi:10.1029/2004JD004508, 2005.

740 Wood, E. F. E. F., Lettenmaier, D. P. D. P. and Zartarian, V. G. V. G.: A Land-Surface Hydrology Parameterization With Subgrid Variability for General Circulation Models, J. Geophys. Res., 97(D3), 2717-2728, doi:10.1029/91JD01786, 1992.

Woodward, J. L.: Estimating the Flammable Mass of a Vapor Cloud, John Wiley \& Sons, Inc., Hoboken, NJ, USA., 1999.

Xia, Y., Mitchell, K., Ek, M., Sheffield, J., Cosgrove, B., Wood, E., Luo, L., Alonge, C., Wei, H., Meng, J., Livneh, B., Lettenmaier, D., Koren, V., Duan, Q., Mo, K., Fan, Y. and Mocko, D.: Continental-scale water and energy flux analysis and

745 validation for the North American Land Data Assimilation System project phase 2 (NLDAS-2): 1. Intercomparison and application of model products, J. Geophys. Res., 117(D3), D03109, doi:10.1029/2011JD016048, 2012.

Xie, Z., Yuan, F., Duan, Q., Zheng, J., Liang, M. and Chen, F.: Regional parameter estimation of the VIC land surface model: Methodology and application to river basins in China, J. Hydrometeorol., 8(3), 447-468, doi:10.1175/JHM568.1, 2007.

Yadav, M., Wagener, T. and Gupta, H.: Regionalization of constraints on expected watershed response behavior for improved

750 predictions in ungauged basins, Adv. Water Resour., 30(8), 1756-1774, doi:10.1016/j.advwatres.2007.01.005, 2007.

Yang, Y., Pan, M., Beck, H. E., Fisher, C. K., Beighley, R. E., Kao, S. C., Hong, Y. and Wood, E. F.: In Quest of Calibration Density and Consistency in Hydrologic Modeling: Distributed Parameter Calibration against Streamflow Characteristics, Water Resour. Res., 55(9), 7784-7803, doi:10.1029/2018WR024178, 2019.

Yang, Z.-L., Niu, G.-Y., Mitchell, K. E., Chen, F., Ek, M. B., Barlage, M., Longuevergne, L., Manning, K., Niyogi, D., Tewari,

755 M. and Xia, Y.: The community Noah land surface model with multiparameterization options (Noah-MP): 2. Evaluation over global river basins, J. Geophys. Res., 116(D12), 1-16, doi:10.1029/2010JD015140, 2011.

Yeste, P., García-Valdecasas Ojeda, M., Gámiz-Fortis, S. R., Castro-Díez, Y. and Esteban-Parra, M. J.: Integrated sensitivity analysis of a macroscale hydrologic model in the north of the Iberian Peninsula, J. Hydrol., 590(September 2019), 125230, doi:10.1016/j.jhydrol.2020.125230, 2020.

760 Zegers, G., Mendoza, P. A., Garces, A. and Montserrat, S.: Sensitivity and identifiability of rheological parameters in debris flow modeling, Nat. Hazards Earth Syst. Sci., 20(7), 1919-1930, doi:10.5194/nhess-20-1919-2020, 2020.

Zhao, R.-J., Zuang, Y.-L., Fang, L.-R., Liu, X.-R. and Zhang, Q.-S.: Xinanjiang Model., IAHS-AISH Publ., (129), 351-356, 1980.

Zink, M., Kumar, R., Cuntz, M. and Samaniego, L.: A high-resolution dataset of water fluxes and states for Germany 765 accounting for parametric uncertainty, Hydrol. Earth Syst. Sci., 21(3), 1769-1790, doi:10.5194/hess-21-1769-2017, 2017. 
Table 1. Summary of sensitivity analysis studies conducted with VIC, that incorporate at least five parameters ${ }^{\mathrm{a}}$.

\begin{tabular}{|c|c|c|c|c|c|c|}
\hline Study & Region & $\begin{array}{l}\text { Number of } \\
\text { sites or } \\
\text { catchments }\end{array}$ & $\begin{array}{l}\text { Target variables or } \\
\text { metrics }\end{array}$ & $\begin{array}{l}\text { Number of } \\
\text { parameters } \\
\text { included in SA }\end{array}$ & Methods & $\begin{array}{l}\text { Most sensitive } \\
\text { parameters }\end{array}$ \\
\hline $\begin{array}{l}\text { Liang \& } \\
\text { Guo } \\
(2003)\end{array}$ & $\begin{array}{l}\text { Red- } \\
\text { Arkansas } \\
\text { River } \\
\text { basin, USA }\end{array}$ & 3 sites & $\begin{array}{l}\text { Annual runoff, } \\
\text { annual ET, annual } \\
\text { mean soil moisture, } \\
\text { and annual mean } \\
\text { sensible heat flux }\end{array}$ & $\begin{array}{l}5 \text { pre-defined } \\
\text { parameters }\end{array}$ & $\begin{array}{l}\text { Fractional Factorial } \\
\text { Analysis (FFA) }\end{array}$ & $\begin{array}{l}\text { Varied with site } \\
\text { characteristics }\end{array}$ \\
\hline $\begin{array}{l}\text { Mendoza } \\
\text { et al. } \\
(2015 b)\end{array}$ & $\begin{array}{l}\text { Colorado } \\
\text { Headwaters } \\
\text { Region, } \\
\text { USA }\end{array}$ & $\begin{array}{l}3 \text { headwater } \\
\text { basins }\end{array}$ & $\begin{array}{l}\mathrm{RMSE}(\mathrm{Q}) \text { with } \mathrm{Q} \text { at } \\
\text { daily time steps }\end{array}$ & $\begin{array}{l}34 \text { soil, } \\
\text { vegetation and } \\
\text { snow } \\
\text { parameters }\end{array}$ & DELSA & $\begin{array}{l}\text { INFILT, Ds, DsMAX, Ws, } \\
\text { Depth2,Depth3, } \\
\text { NEW_ALB,ALB_AA, } \\
\text { ALB_THA }\end{array}$ \\
\hline $\begin{array}{l}\text { Bennett } \\
\text { et al. } \\
(2018)\end{array}$ & $\begin{array}{l}\text { Colorado } \\
\text { River } \\
\text { basin, USA }\end{array}$ & $\begin{array}{l}7 \text { grid cells } \\
\text { across the } \\
\text { basin, } \\
\text { with } \sim 7 \mathrm{~km} \\
\text { horizontal } \\
\text { resolution }\end{array}$ & $\begin{array}{l}\text { Projected changes } \\
\text { (i.e., 2070-2099 } \\
\text { minus 1970-1999 } \\
\text { averages) in mean } \\
\text { annual runoff, June } \\
\text { soil moisture, March } \\
\text { SWE and annual ET }\end{array}$ & $\begin{array}{l}46 \text { soil and } \\
\text { vegetation } \\
\text { parameters }\end{array}$ & $\begin{array}{l}\text { Variance-based } \\
\text { Sensitivity } \\
\text { Analysis, applied to } \\
\text { a Gaussian process } \\
\text { emulator developed } \\
\text { for VIC at each grid } \\
\text { cell }\end{array}$ & $\begin{array}{l}D s M A X, D s \text { and Depth3 } \\
\text { for projected changes in } \\
\text { runoff, ET and soil } \\
\text { moisture; wintertime } \\
\text { canopy fraction and } \\
\text { wintertime } L A I \text { for } \\
\text { projected changes in SWE }\end{array}$ \\
\hline
\end{tabular}




\begin{tabular}{|c|c|c|c|c|c|c|}
\hline Study & Region & $\begin{array}{l}\text { Number of } \\
\text { sites or } \\
\text { catchments }\end{array}$ & $\begin{array}{l}\text { Target variables or } \\
\text { metrics }\end{array}$ & $\begin{array}{l}\text { Number of } \\
\text { parameters } \\
\text { included in SA }\end{array}$ & Methods & $\begin{array}{l}\text { Most sensitive } \\
\text { parameters }\end{array}$ \\
\hline $\begin{array}{l}\text { Gou et } \\
\text { al. } \\
(2020)\end{array}$ & $\begin{array}{l}10 \text { major } \\
\text { river basins } \\
\text { in China }\end{array}$ & $\begin{array}{l}14 \\
\text { catchments }\end{array}$ & $\begin{array}{l}\text { NSE(Q) with Q at } \\
\text { monthly time steps }\end{array}$ & $\begin{array}{l}13 \text { soil } \\
\text { parameters }\end{array}$ & $\begin{array}{l}\text { Three qualitative } \\
\text { (SOT, MARS, DT) } \\
\text { and one quantitative } \\
\text { (Sobol') method }\end{array}$ & $\begin{array}{l}\text { INFILT, Depth1 and } \\
\text { Depth } 2 \text { are the overall } \\
\text { most influential } \\
\text { parameters on streamflow }\end{array}$ \\
\hline $\begin{array}{l}\text { Yeste et } \\
\text { al. } \\
(2020)\end{array}$ & $\begin{array}{l}\text { Duero } \\
\text { River } \\
\text { basin, } \\
\text { Iberian } \\
\text { Peninsula }\end{array}$ & $\begin{array}{l}31 \text { headwater } \\
\text { basins }\end{array}$ & $\begin{array}{l}\text { Temporal averages } \\
\text { of surface runoff, } \\
\text { baseflow, total } \\
\text { runoff, ET, and total } \\
\text { soil moisture }\end{array}$ & $\begin{array}{l}5 \text { soil } \\
\text { parameters }\end{array}$ & SRC & $\begin{array}{l}\text { Surface runoff, baseflow, } \\
\text { total runoff, ET and SM1 } \\
\text { are mainly sensitive to } \\
I N F I L T \text { and Depth2. SM2 } \\
\text { affected mostly by } \\
\text { Depth2, and SM3 affected } \\
\text { by Ds, DsMAX and } W s\end{array}$ \\
\hline $\begin{array}{l}\text { Melsen } \\
\text { and } \\
\text { Guse } \\
(2021)\end{array}$ & $\begin{array}{l}\text { Contiguous } \\
\text { United } \\
\text { States } \\
\text { (CONUS) }\end{array}$ & $\begin{array}{l}605 \\
\text { catchments }\end{array}$ & $\begin{array}{l}\text { Mean simulated } \\
\text { streamflow and the } \\
\text { day of the year when } \\
\text { half of the } \\
\text { streamflow volume } \\
\text { has passed (i.e., } \\
\text { streamflow timing) }\end{array}$ & $\begin{array}{l}17 \text { soil, } \\
\text { vegetation and } \\
\text { snow } \\
\text { parameters }\end{array}$ & DELSA & $\begin{array}{l}\text { Rmin, Depth2 and Expt2 } \\
\text { are the most sensitive } \\
\text { parameter for mean } \\
\text { annual discharge; Ds, } \\
\text { DsMAX, Depth2, Rmin, } \\
\text { Expt } 2 \text { and Depth3 control } \\
\text { streamflow timing }\end{array}$ \\
\hline $\begin{array}{l}\text { This } \\
\text { study }\end{array}$ & $\begin{array}{l}\text { Continental } \\
\text { Chile }\end{array}$ & $\begin{array}{l}5,574 \text { grid } \\
\text { cells } \\
\left(0.05^{\circ} \times 0.05^{\circ}\right) \\
\text { across } 101 \\
\text { basins }\end{array}$ & $\begin{array}{l}8 \text { metrics computed } \\
\text { at daily time steps }\end{array}$ & $\begin{array}{l}43 \text { soil, } \\
\text { vegetation and } \\
\text { snow } \\
\text { parameters }\end{array}$ & DELSA & $\begin{array}{l}\text { INFILT, Ds, DsMAX, Ws, } \\
\text { Expt2,Depth2,Depth3, } \\
\text { Rmin, LAI, NEW_ALB, } \\
\text { ALB_THA,ALB_AA }\end{array}$ \\
\hline
\end{tabular}

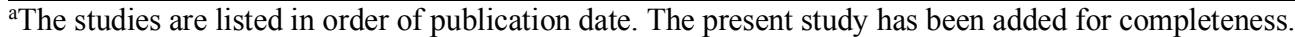

${ }^{b}$ We exclude two routing parameters that were found sensitive, but were not used in the other studies.

FFA: Factorial Fractional Analysis (Montgomery, 1991)

775 DELSA: Distributed Evaluation of Local Sensitivity Analysis (Rakovec et al., 2014).

DT: Delta test (Pi and Peterson, 1994).

SOT: Sum-Of-Trees model (Chipman et al., 2010).

MARS: Multivariate Adaptive Regression Splines (Friedman, 1991).

VARS: Variariogram Analysis of Response Surfaces (Razavi and Gupta, 2016).

780 SRC: Standardized Regression Coefficients (Saltelli et al., 2008).

VISCOUS: Varlance-based Sensitivity analysis using COp- UlaS (Sheikholeslami et al., 2021). 
Table 2. List of physiographic and hydroclimatic attributes used to characterize model grid cells.

\begin{tabular}{|l|l|l|l|}
\hline Predictor & Class & Description & Data source \\
\hline Elevation & Topographic & Mean elevation (m.a.s.l.) & DGA (2018, 2019, 2020) \\
\hline Slope & Topographic & Mean topographic slope $\left({ }^{\circ}\right)$ & $\begin{array}{l}\text { Digital Elevation SRTM 1 Arc-Second Global } \\
(\text { https://earthexplorer.usgs.gov/) }\end{array}$ \\
\hline Precipitation & Climate & Mean annual precipitation $(\mathrm{mm} / \mathrm{yr})$ & CR2MET (Boisier et al., 2018) (https://www.cr2.cl/) \\
\hline Temperature & Climate & Mean temperature $\left({ }^{\circ} \mathrm{C}\right)$ & CR2MET (Boisier et al., 2018) (https://www.cr2.cl/) \\
\hline Humidity & Climate & Mean relative humidity (-) & CR2MET (Boisier et al., 2018) (https://www.cr2.cl/) \\
\hline Aridity & Climate & $\begin{array}{l}\text { Aridity index }(-), \text { ratio of long-term } \\
\text { potential evaporation to precipitation }\end{array}$ & - \\
\hline Clay & Soil & Soil clay content $(\%)$ average over all layers & $\begin{array}{l}\text { SoilGrids250m }(\text { Hengl et al., } 2017) \\
(\text { https://soilgrids.org/) }\end{array}$ \\
\hline Bare soil & Land cover & Fraction of bare soil & DGA $(2018,2019,2020)$ \\
\hline Forest & Land cover & Fraction of forest & DGA $(2018,2019,2020)$ \\
\hline Grasslands & Land cover & Fraction of grasslands & DGA $(2018,2019,2020)$ \\
\hline Shrub & Land cover & Fraction of shrub & DGA $(2018,2019,2020)$ \\
\hline Snow & Land cover & Fraction of snow cover & DGA $(2018,2019,2020)$ \\
\hline
\end{tabular}

Table 3. Parameters of the VIC model considered in this study.

\begin{tabular}{|c|c|c|c|c|c|}
\hline Parameter & Description & Units & Min & Max & Comment \\
\hline \multicolumn{6}{|c|}{ Soil parameters } \\
\hline INFILT & $\begin{array}{l}\text { Variable infiltration curve } \\
\text { parameter }\end{array}$ & - & 0.001 & 0.4 & $\begin{array}{l}\text { Based on Mendoza et al. } \\
(2015 b)\end{array}$ \\
\hline Ds MAX & Maximum velocity of baseflow & $\mathrm{mm} / \mathrm{d}$ & 1 & 50 & $\begin{array}{l}\text { Based on Melsen et al., } \\
\text { (2016) }\end{array}$ \\
\hline Ds & $\begin{array}{l}\text { Fraction of } \mathrm{Ds}_{\max } \text { where non- } \\
\text { linear baseflow occurs }\end{array}$ & - & 0.00005 & 1 & $\begin{array}{l}\text { Based on Mendoza et al. } \\
(2015 b)\end{array}$ \\
\hline Ws & $\begin{array}{l}\text { Fraction of maximum soil } \\
\text { moisture where non-linear } \\
\text { baseflow occurs }\end{array}$ & - & 0.0009 & 1 & $\begin{array}{l}\text { Based on Mendoza et al. } \\
(2015 b)\end{array}$ \\
\hline $\mathrm{c}$ & Exponent used in baseflow curve & - & 1 & 4 & $\begin{array}{l}\text { Based on Melsen et al. } \\
\text { (2016) }\end{array}$ \\
\hline Expt $_{\mathrm{i}}$ & $\begin{array}{l}\text { Exponent in Campbell's equation } \\
\text { for hydraulic conductivity of soil } \\
\text { layer i }\end{array}$ & - & 5 & 30 & $\begin{array}{l}\text { Based on Melsen et al. } \\
\text { (2016) }\end{array}$ \\
\hline $\mathrm{Ksat}_{\mathrm{i}}$ & $\begin{array}{l}\text { Saturated hydraulic conductivity } \\
\text { of soil layer i }\end{array}$ & $\mathrm{mm} / \mathrm{d}$ & 1 & 10000 & $\begin{array}{l}\text { Based on Demaria et al. } \\
(2007)\end{array}$ \\
\hline Depth $_{1}$ & Thickness of layer 1 (uppermost) & $\mathrm{m}$ & 0.01 & 0.5 & $\begin{array}{l}\text { Based on Demaria et al. } \\
(2007)\end{array}$ \\
\hline Depth $_{2}$ & Thickness of layer 2 & $\mathrm{~m}$ & Depth $_{1}+0.1$ & Depth $_{1}+4$ & $\begin{array}{l}\text { Based on Melsen et al. } \\
(2016)\end{array}$ \\
\hline Depth $_{3}$ & Thickness of layer 3 (lowermost) & $\mathrm{m}$ & 0.1 & 4 & $\begin{array}{l}\text { Based on Melsen et al. } \\
\text { (2016) }\end{array}$ \\
\hline $\mathrm{dp}$ & Soil thermal damping depth & $\mathrm{m}$ & 1 & 3.75 & $\begin{array}{l}\text { Based on Gates \& Evans } \\
\text { (1964) and Al }\end{array}$ \\
\hline
\end{tabular}




\begin{tabular}{|c|c|c|c|c|c|}
\hline Parameter & Description & Units & Min & Max & Comment \\
\hline & & & & & $\begin{array}{l}\text { Nakshabandi \& Kohnke } \\
\text { (1965) }\end{array}$ \\
\hline quartz $\mathrm{i}_{\mathrm{i}}$ & Quartz content of soil layer i & - & 0.1 & 0.82 & $\begin{array}{l}\text { Based on Hogue et al. } \\
\text { (2005) and Rosero et al. } \\
(2010)\end{array}$ \\
\hline bulk densityi & Bulk density of layer i & $\mathrm{kg} / \mathrm{m}^{3}$ & 1200 & 1609 & $\begin{array}{l}\text { Based on Cosby et al. } \\
\text { (1984); Rawls et al. (1992) } \\
\text { and Reynolds et al. (2000) }\end{array}$ \\
\hline rough & Surface roughness of bare soil & $\mathrm{m}$ & 0.0001 & 0.08 & $\begin{array}{l}\text { Based on Woodward } \\
\text { (1999) }\end{array}$ \\
\hline Resid moist & Residual soil moisture of layer i & - & 0.02 & 0.109 & $\begin{array}{l}\text { Based on Rawls et al. } \\
\text { (1992) }\end{array}$ \\
\hline \multicolumn{6}{|c|}{ Vegetation parameters } \\
\hline rarc & $\begin{array}{l}\text { Architectural resistance of } \\
\text { vegetation type }\end{array}$ & $\mathrm{s} / \mathrm{m}$ & 2 & 50 & $\begin{array}{l}\text { Based on Ducoudré et al. } \\
\text { (1993) }\end{array}$ \\
\hline Rmin & $\begin{array}{l}\text { Minimum stomatal resistance of } \\
\text { vegetation type }\end{array}$ & $\mathrm{s} / \mathrm{m}$ & 30 & 300 & $\begin{array}{l}\text { Based on Melsen et al. } \\
(2016)\end{array}$ \\
\hline LAI* & $\begin{array}{l}\text { Leaf-area index of vegetation } \\
\text { type }\end{array}$ & - & 0.1 & 1.16 & $\begin{array}{l}\text { Multipliers obtained from } \\
\text { leaf-area index range 0.01- } \\
7 \text { based on Dorman \& } \\
\text { Sellers (1989) and Myneni } \\
\text { et al. (1997) }\end{array}$ \\
\hline ALB* & $\begin{array}{l}\text { Shortwave albedo for vegetation } \\
\text { type }\end{array}$ & - & 1 & 1.65 & $\begin{array}{l}\text { Multiplier obtained from } \\
\text { shortwave albedo range } \\
0.1-0.33 \text { based on Dorman } \\
\text { \& Sellers (1989) }\end{array}$ \\
\hline ROU* & Vegetation roughness length & - & 0.82 & 2.11 & $\begin{array}{l}\text { Multiplier obtained from } \\
\text { roughness length range } \\
0.06-2.6 \text { m based on } \\
\text { Dorman \& Sellers (1989) }\end{array}$ \\
\hline DIS* & Vegetation displacement height & - & 0.82 & 2.11 & $\begin{array}{l}\text { Multiplier obtained from } \\
\text { roughness length range } \\
0.06-2.6 \text { m based on } \\
\text { Dorman \& Sellers (1989) } \\
\text { and VIC definitions }\end{array}$ \\
\hline Root depth i & $\begin{array}{l}\text { Root zone thickness (sum of } \\
\text { depths is total depth of root } \\
\text { penetration) of layer i }\end{array}$ & $\mathrm{m}$ & 0.1 & 3 & $\begin{array}{l}\text { Based on Melsen et al. } \\
\text { (2016) }\end{array}$ \\
\hline Root fraction $\mathrm{i}$ & $\begin{array}{l}\text { Fraction of root in the current } \\
\text { root zone of layer i. }\end{array}$ & - & 0 & 1 & $\begin{array}{l}\text { Based on Bohn \& Vivoni } \\
(2016)\end{array}$ \\
\hline \multicolumn{6}{|c|}{ Snow and general parameters } \\
\hline z0 SNOW & Surface roughness of snowpack & $\mathrm{m}$ & 0.0001 & 0.01 & $\begin{array}{l}\text { Based on range suggested } \\
\text { by Marks \& Dozier (1992) } \\
\text { and Reba et al. (2014) }\end{array}$ \\
\hline Tmin & $\begin{array}{l}\text { Minimum temperature at which } \\
\text { rain can fall. }\end{array}$ & ${ }^{\circ} \mathrm{C}$ & -1.5 & 0 & $\begin{array}{l}\text { Based on Melsen et al. } \\
(2016)\end{array}$ \\
\hline
\end{tabular}




\begin{tabular}{|l|l|l|l|l|l|}
\hline Parameter & Description & Units & Min & Max & Comment \\
\hline Tmax & $\begin{array}{l}\text { Maximum temperature at which } \\
\text { snow can fall. }\end{array}$ & ${ }^{\circ} \mathrm{C}$ & Tmin +0.5 & Tmin +1.5 & $\begin{array}{l}\text { Based on Melsen et al. } \\
(2016)\end{array}$ \\
\hline NEW ALB & New snow albedo & - & 0.7 & 0.99 & $\begin{array}{l}\text { Based on Mendoza et al. } \\
(2015 b)\end{array}$ \\
\hline ALB AA & $\begin{array}{l}\text { Base in snow albedo function } \\
\text { (accumulation) }\end{array}$ & - & 0.88 & 0.99 & $\begin{array}{l}\text { Based on Mendoza et al. } \\
(2015 b)\end{array}$ \\
\hline ALB THA & $\begin{array}{l}\text { Base in snow albedo function } \\
\text { (melt) }\end{array}$ & - & 0.66 & 0.98 & $\begin{array}{l}\text { Based on Mendoza et al. } \\
(2015 b)\end{array}$ \\
\hline
\end{tabular}

*This parameter is temporally distributed (monthly variations) and, therefore, its sensitivity is analyzed based on multipliers. Although description and units refer to actual parameters of VIC, parameter values in bold represent the multiplier values

(instead of actual parameters).

Table 4. Parameter sensitivity metrics used in this study.

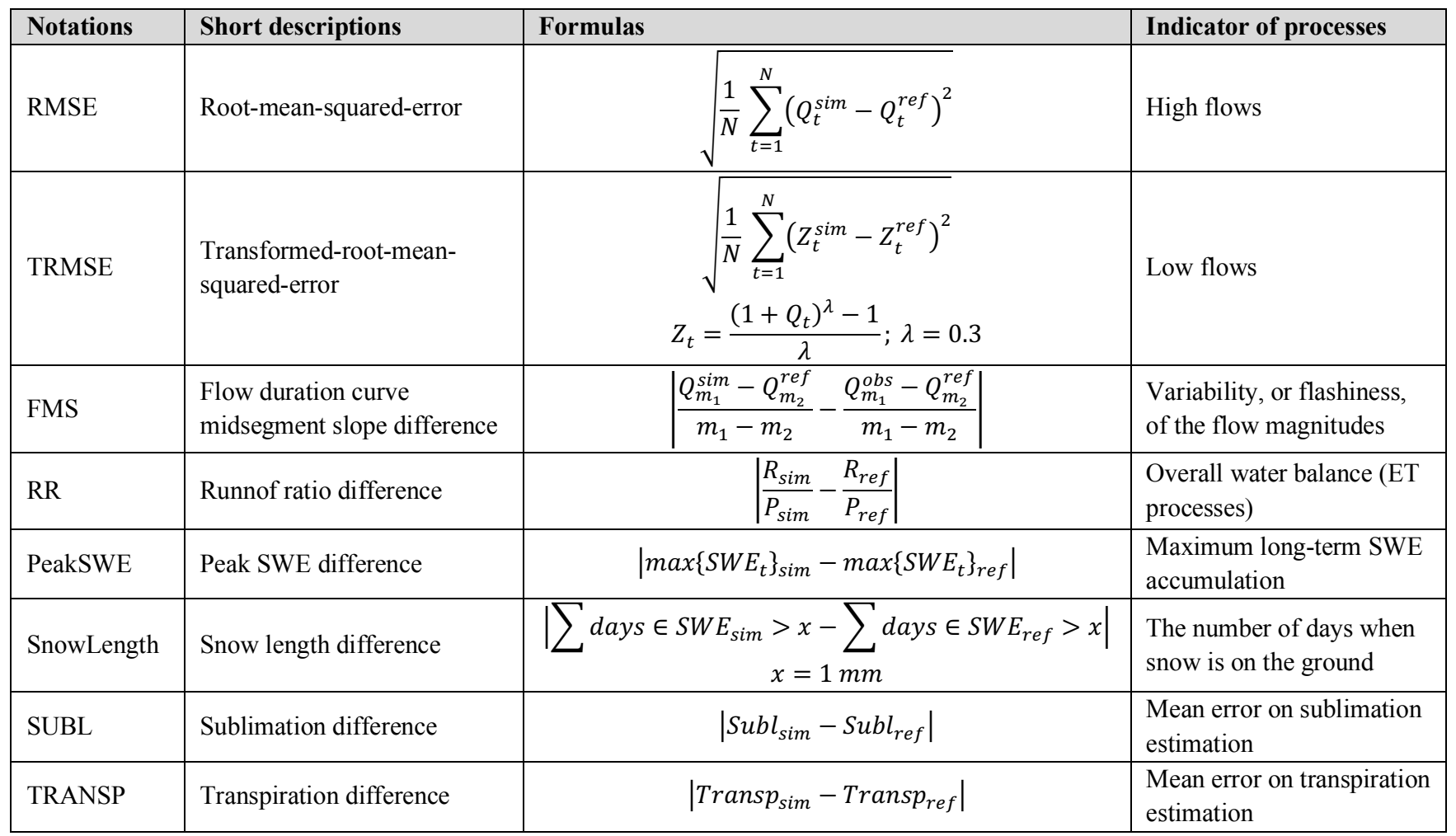

$\mathrm{N}$, number of time steps; $Q_{t}$, flow for time step $\mathrm{t} ; Z_{t}$, flow transformed for time step $\mathrm{t} ; Q_{m_{1}}, m_{1}$ percentile flow of simulated flow duration curve; $m_{1}=70 ; Q_{m_{2}}, m_{2}$ percentile flow of simulated flow duration curve; $m_{2}=30$; R, grid-averaged mean 795 annual runnof; $\mathrm{P}$, grid-averaged mean annual precipitation; $S W E_{t}$, Snow water equivalent for time step t; Subl, grid-averaged mean annual sublimation; Transp, grid-averaged mean annual transpiration. 
Table 5. Climate classification used to group model grid cells.

\begin{tabular}{|l|c|c|c|c|c|c|}
\hline Classification & Humid & Humid sub-humid & Dry sub-humid & Semi-arid & Arid & Hyper arid \\
\hline Aridity index & $<1$ & 1 to 1.53 & 1.53 to 2 & 2 to 5 & 5 to 20 & $>20$ \\
\hline Number of grid cells & 2189 & 772 & 318 & 992 & 803 & 499 \\
\hline
\end{tabular}

Table 6. Summary with the most sensitive VIC parameters found for each metric (rows) and climatic type. The three most important parameters are determined based on the median of integrated first-order DELSA sensitivity indices and are sorted by ranking (i.e., $1^{\text {st }}, 2^{\text {nd }}$, and $3^{\text {rd }}$ most sensitive).

\begin{tabular}{|l|l|l|l|l|l|l|}
\hline \multicolumn{1}{|c|}{ Classification } & Humid & $\begin{array}{c}\text { Humid sub- } \\
\text { humid }\end{array}$ & \multicolumn{1}{|c|}{$\begin{array}{c}\text { Dry sub- } \\
\text { humid }\end{array}$} & \multicolumn{1}{|c|}{ Semi-arid } & \multicolumn{1}{|c|}{ Arid } & \multicolumn{1}{c|}{ Hyper arid } \\
\hline \multirow{3}{*}{ RMSE } & Ds MAX & Ds MAX & INFILT & INFILT & INFILT & INFILT \\
& Ws & Ws & Ws & Expt 2 & Expt 2 & Expt 2 \\
& Depth 3 & Depth 3 & Ds MAX & Depth 2 & Depth 2 & Depth 2 \\
\hline \multirow{3}{*}{ TRMSE } & Ds MAX & LAI & LAI & INFILT & INFILT & INFILT \\
& Ws & Ds MAX & Depth 2 & Depth 2 & Expt 2 & Expt 2 \\
& Ds & Ds & Ds & Expt 2 & Depth 2 \\
\hline \multirow{3}{*}{ FMS } & Ds MAX & Ds & Ds & Ds & Depth 2 & Depth 2 \\
& Ds & Ds MAX & Ds MAX & Ds MAX & Expt 2 & Expt 2 \\
& Ws & LAI & LAI & Depth 2 & Ds & Ds \\
\hline \multirow{3}{*}{ RR } & LAI & LAI & LAI & LAI & INFILT & Depth 2 \\
& Rmin & Rmin & Expt 2 & Expt 2 & Depth 1 & INFILT \\
& Expt 2 & Expt 2 & Depth 2 & Depth 2 & Expt 2 & Depth 1 \\
\hline \multirow{3}{*}{ PeakSWE } & NEW ALB & NEW ALB & NEW ALB & NEW ALB & NEW ALB & NEW ALB \\
& ALB THA & ALB THA & z0 SNOW & ALB AA & ALB AA & ALB AA \\
& LAI & ALB AA & ALB THA & T max & z0 SNOW & z0 SNOW \\
\hline \multirow{3}{*}{ SnowLength } & NEW ALB & NEW ALB & NEW ALB & NEW ALB & NEW ALB & NEW ALB \\
& ALB THA & ALB AA & ALB AA & ALB AA & ALB AA & ALB AA \\
& ALB AA & ALB THA & ALB THA & T max & ALB THA & z0 SNOW \\
\hline \multirow{3}{*}{ SUBL } & z0 SNOW & NEW ALB & z0 SNOW & NEW ALB & NEW ALB & NEW ALB \\
& NEW ALB & z0 SNOW & NEW ALB & z0 SNOW & z0 SNOW & ALB AA \\
& ALB THA & T max & T max & ALB AA & ALB AA & z0 SNOW \\
\hline \multirow{3}{*}{ TRANSP } & LAI & LAI & LAI & LAI & Expt 2 & Expt 2 \\
& Rmin & Rmin & Depth 2 & Depth 2 & LAI & Depth 2 \\
& Expt 2 & Depth 2 & Expt 2 & Expt 2 & Depth 2 & LAI \\
\hline
\end{tabular}


https://doi.org/10.5194/hess-2021-550

Preprint. Discussion started: 22 November 2021

(c) Author(s) 2021. CC BY 4.0 License.

(a) Mean annual

(b) Mean annual

(c) Mean elevation

[m.a.s.l.] (d) Aridity index [-]

(e) Bare soil
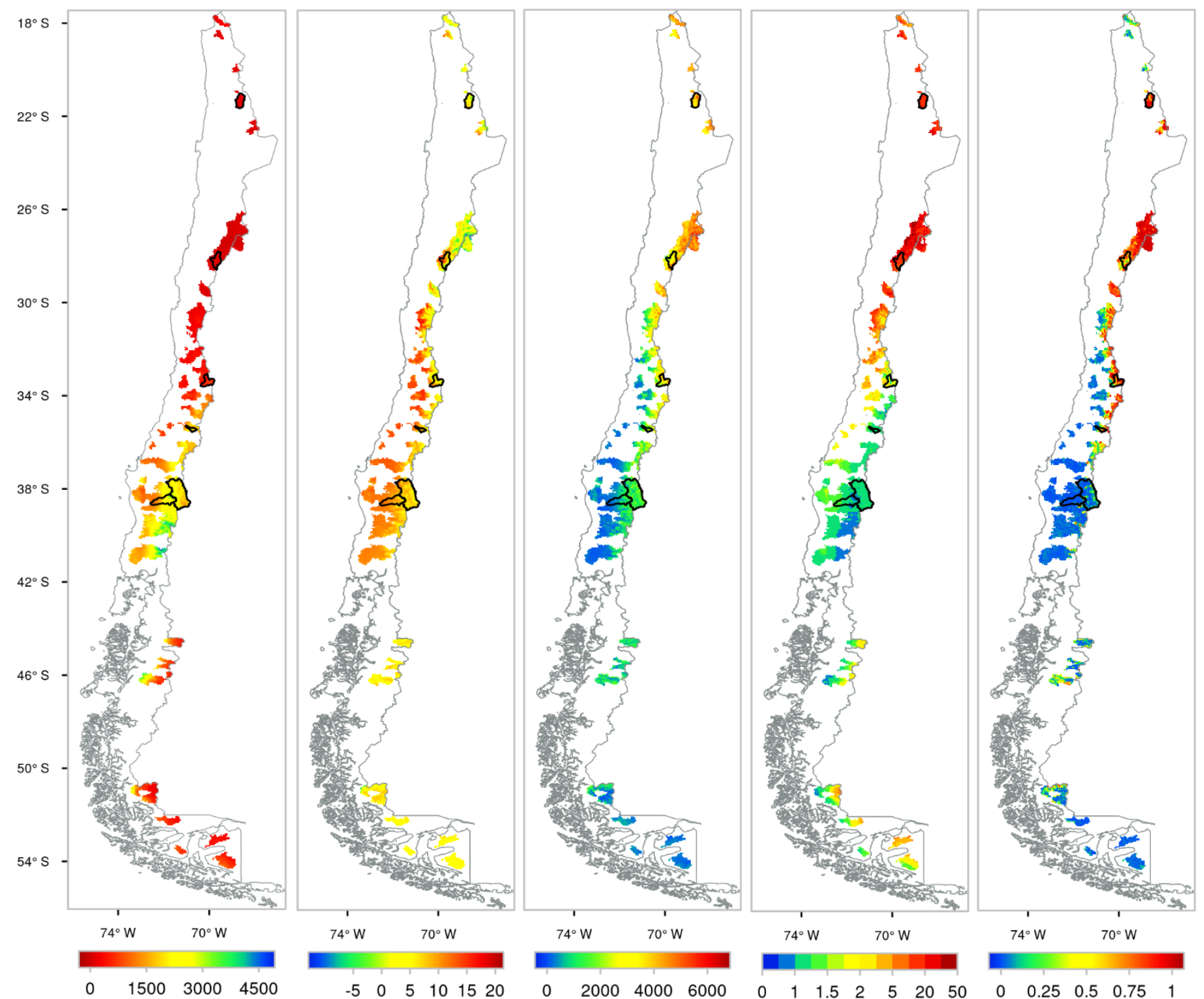

Figure 1. Spatial distribution of climatic and physiographic attributes across all grid cells: (a) mean annual precipitation (period 1979 - 2020), (b) mean annual temperature (period 1979 - 2020), (c) mean elevation, (d) aridity index and (e) bare soil fraction. In each panel, the back thick lines represent the boundaries of six basins representative of the hydroclimatic diversity within the study domain, from north to south: (a) Loa River upstream Lequena reservoir; (b) Pulido River at Vertedero; (c) Colorado River before junction with Maipo River; (d) Palos River at junction with Colorado River; (e) Biobío River at Rucalhue; (f) Cautin River at Cajon. 
https://doi.org/10.5194/hess-2021-550

Preprint. Discussion started: 22 November 2021

(c) Author(s) 2021. CC BY 4.0 License.

(c) (i)
Hydrology and

Earth System

Sciences

Discussions

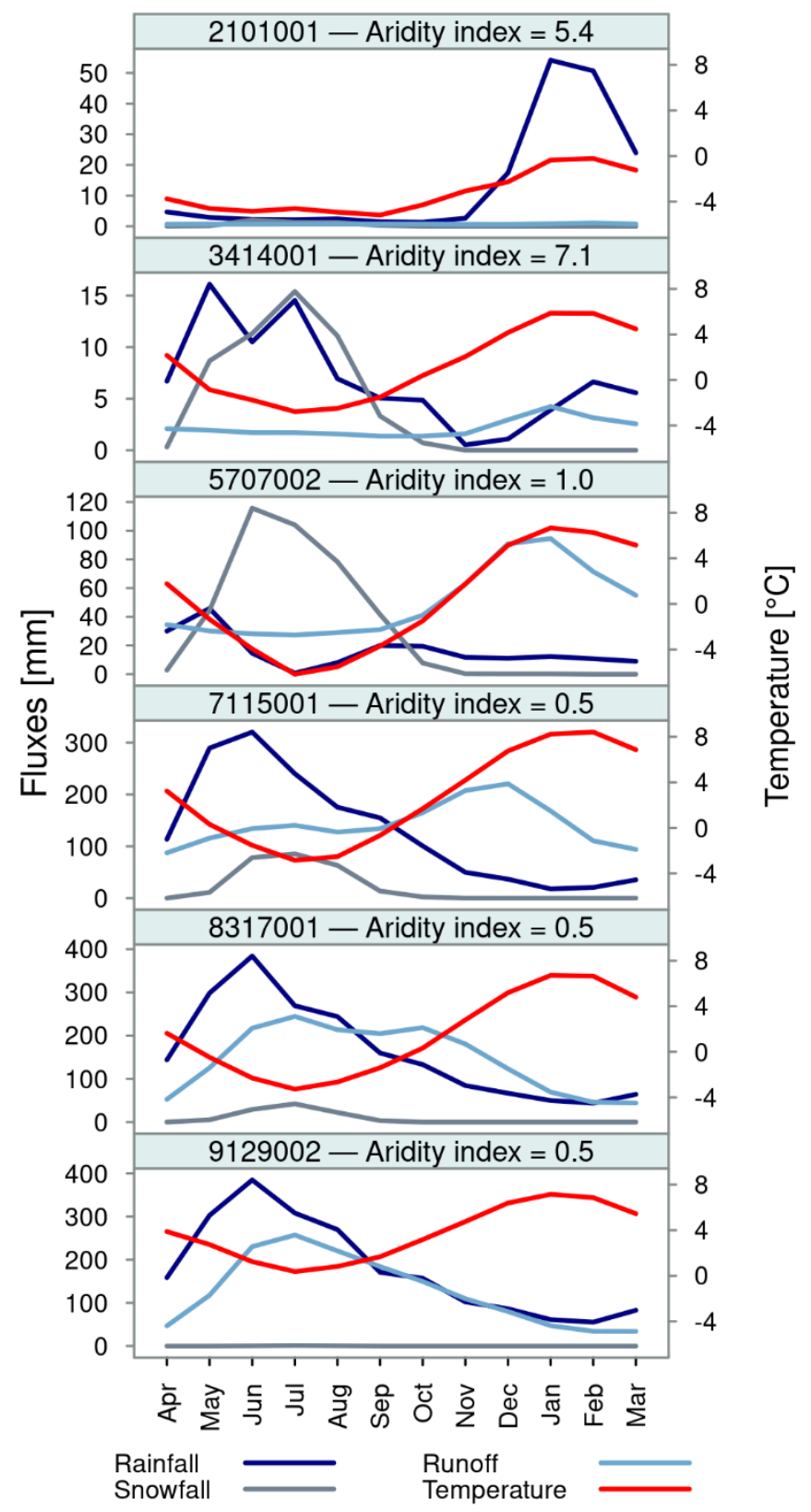

Figure 2. Seasonal cycles of catchment-averaged precipitation, runoff and temperature (period 1981 - 2018 ) for six basins representative of the hydroclimatic diversity within the study domain. From north to south: (a) Loa River upstream Lequena reservoir; (b) Pulido River at Vertedero; (c) Colorado River before junction with Maipo River; (d) Palos River at junction with Colorado River; (e) Biobío River at Rucalhue; (f) Cautin River at Cajon. The location of these catchments is shown in Figure 1. 


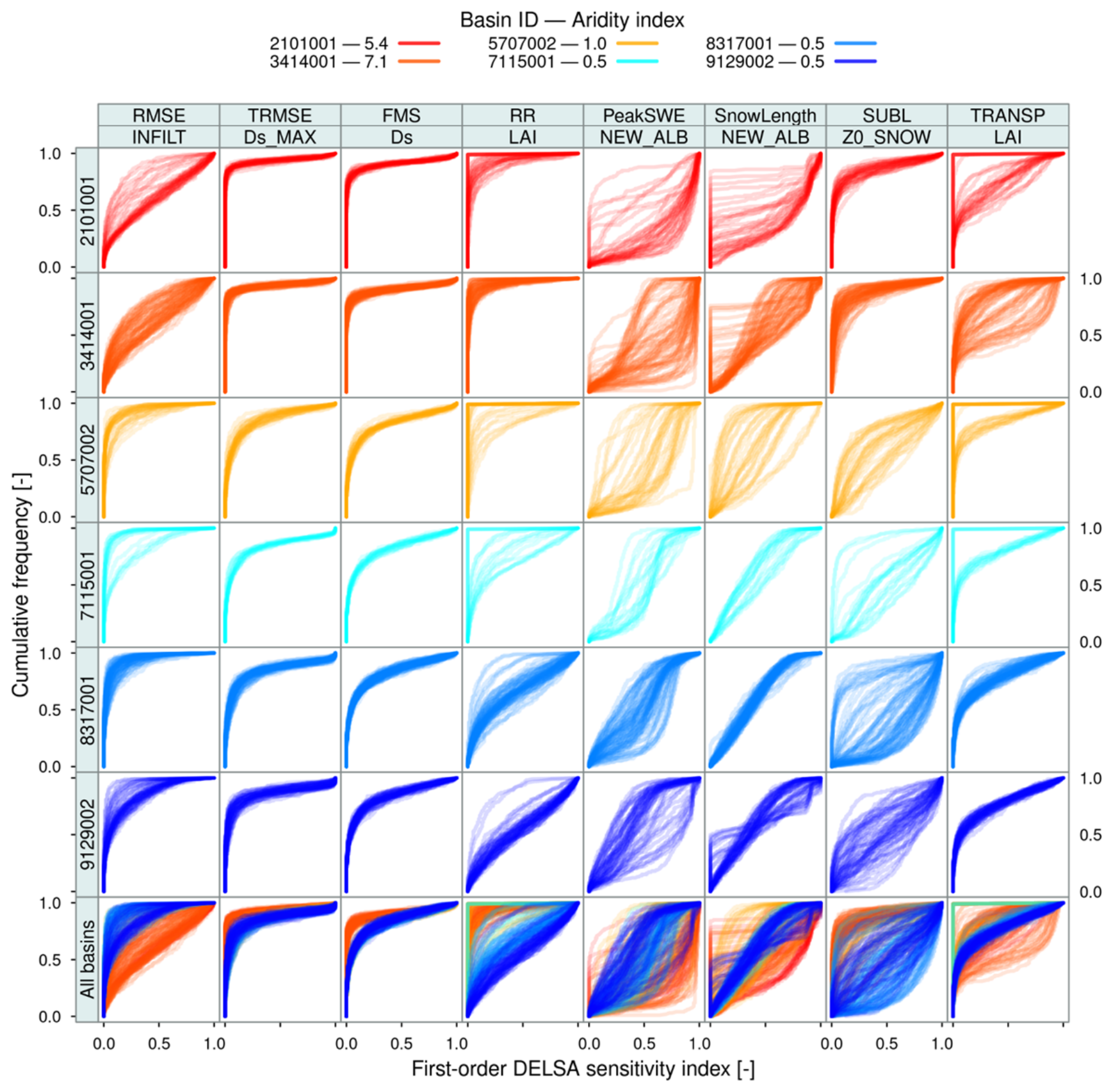

Figure 3. Comparison of cumulative frequency distributions of first-order DELSA indices $\left(S_{j}^{L}\right)$ across six hydroclimatically different basins (displayed in different rows). The location and seasonal cycles for these basins are displayed in Figures 1 and 2, respectively. Results are displayed for the most sensitive parameter associated with each evaluation metric (displayed in different columns), so each panel (excepting those in the last row) comprises the CDFs of all grid cells contained in a specific basin, for a particular combination of metric/parameter. The most sensitive parameter was determined based on the median sensitivity index $I S_{j}^{L}$ from all the grid cells contained in the study domain (see text for details). The number next to each basin code at the top of this figure is the catchment-scale aridity index. 


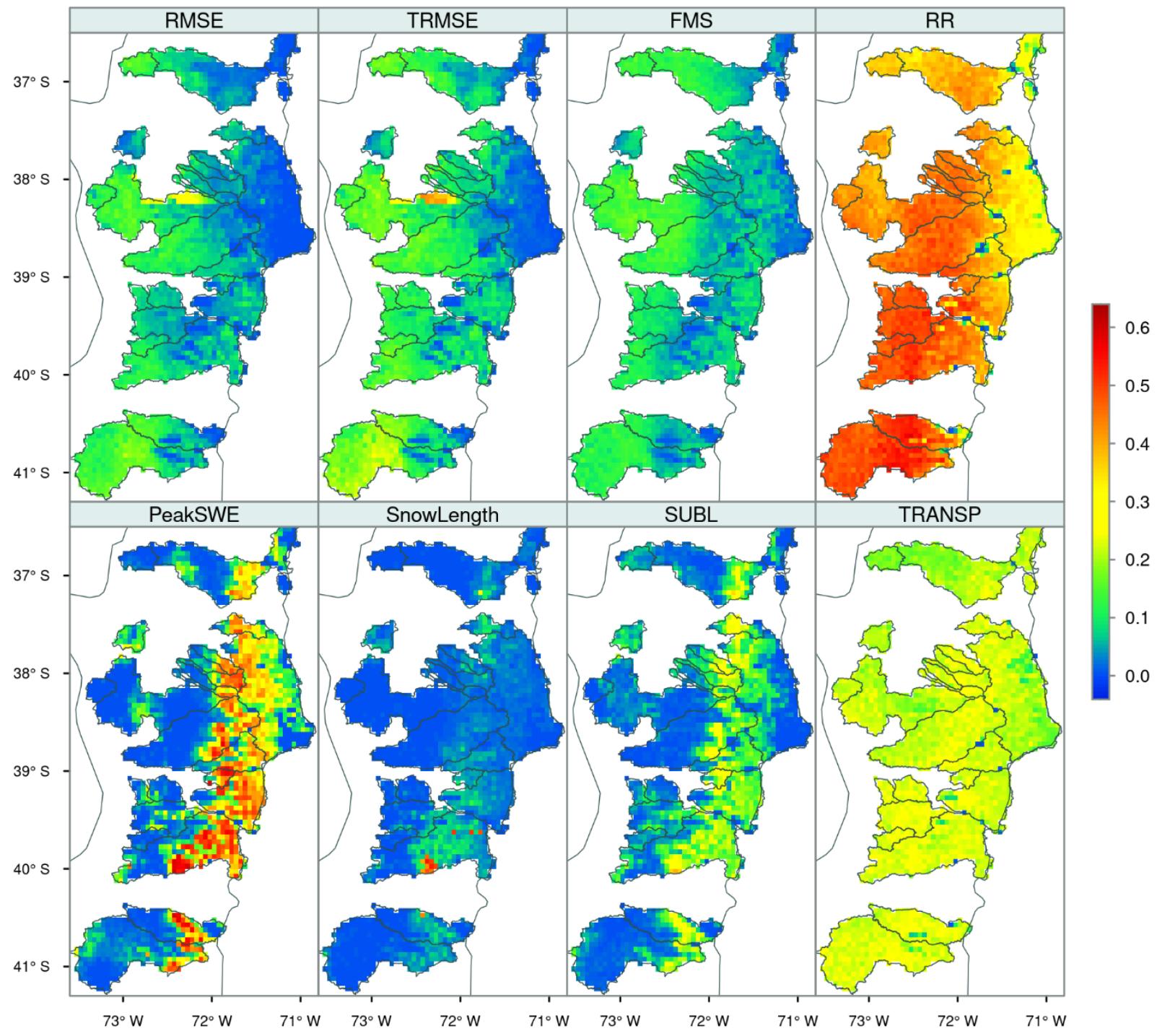

Figure 4. Spatial distribution of integrated first-order DELSA sensitivity indices $\left(I S_{j}^{L}\right)$ for the leaf area index ( $\left.L A I\right)$ across a humid subdomain located in Southern Chile. Results are displayed for eight sensitivity metrics: (a) RMSE, (b) TRMSE; (c) FMS; (d) RR; (e) PeakSWE; (f) SnowLength; (g) SUBL; (h) TRANSP. 
https://doi.org/10.5194/hess-2021-550

Hydrology and

Preprint. Discussion started: 22 November 2021

(c) Author(s) 2021. CC BY 4.0 License.

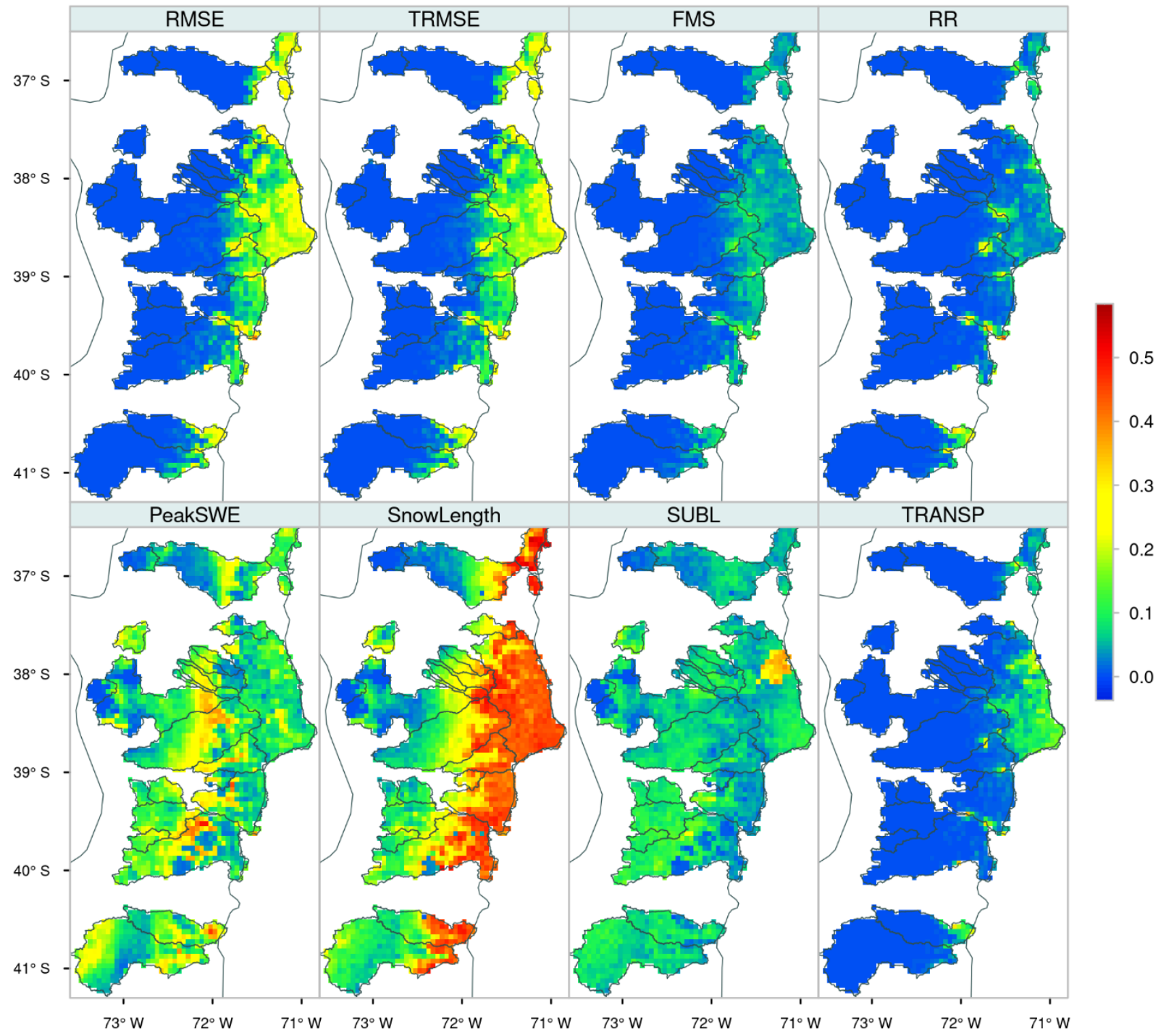

Figure 5. Same as in Figure 4, but for the base in the snow albedo function $A L B T H A$ (melt). 


\section{(a)}

(b)

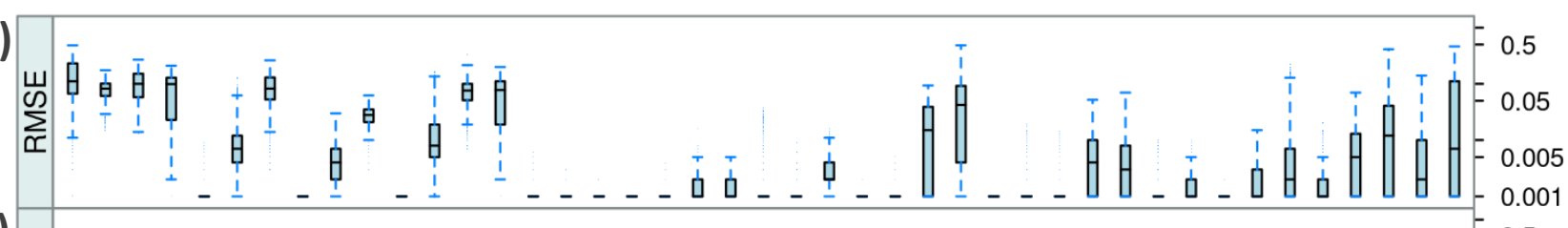

(c)
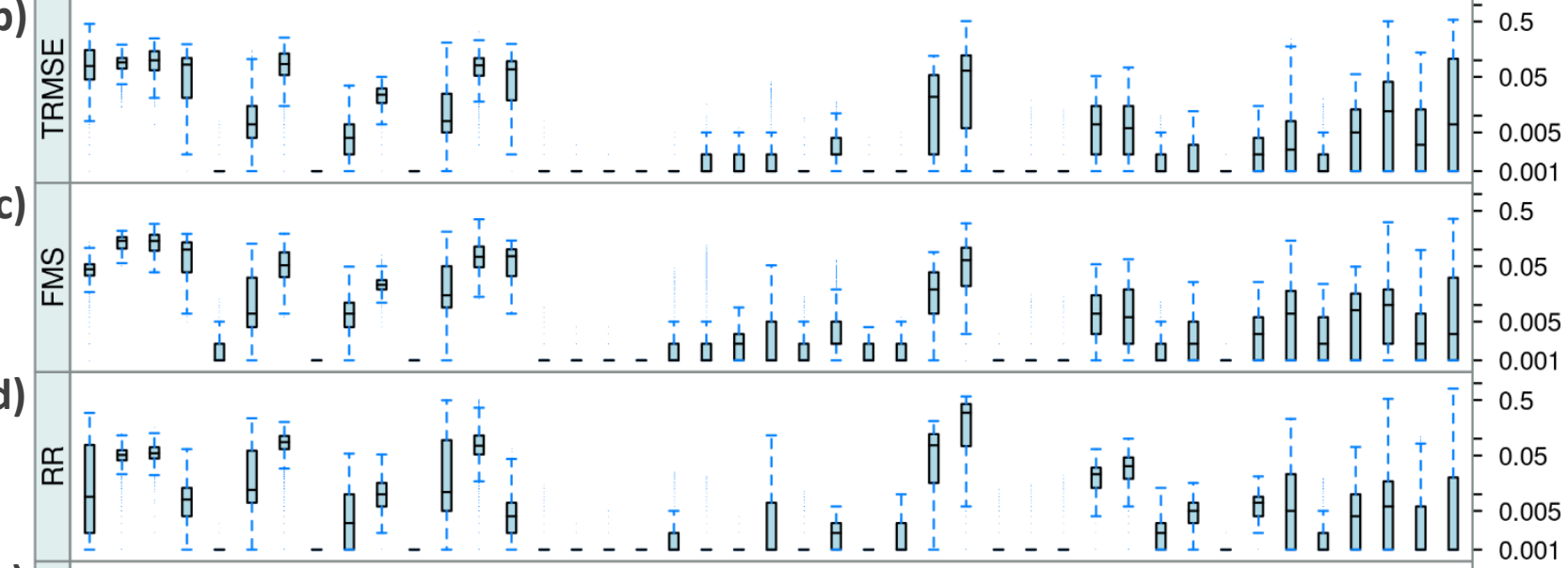

(e)

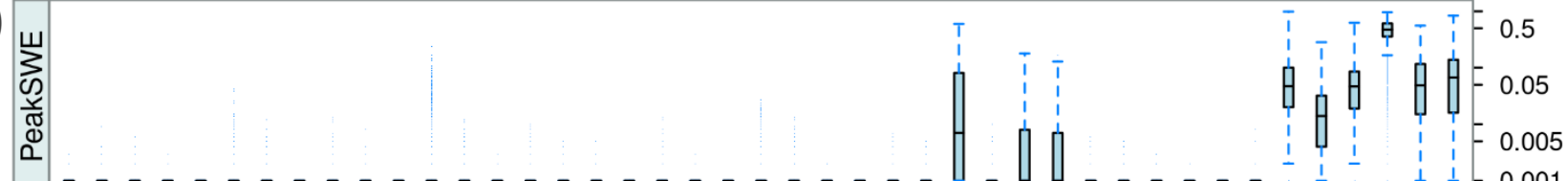

(f)

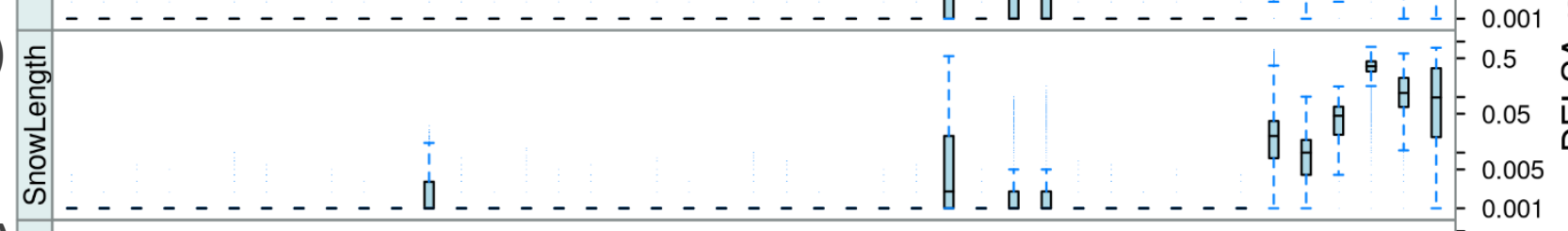

(g)

g)

(h)

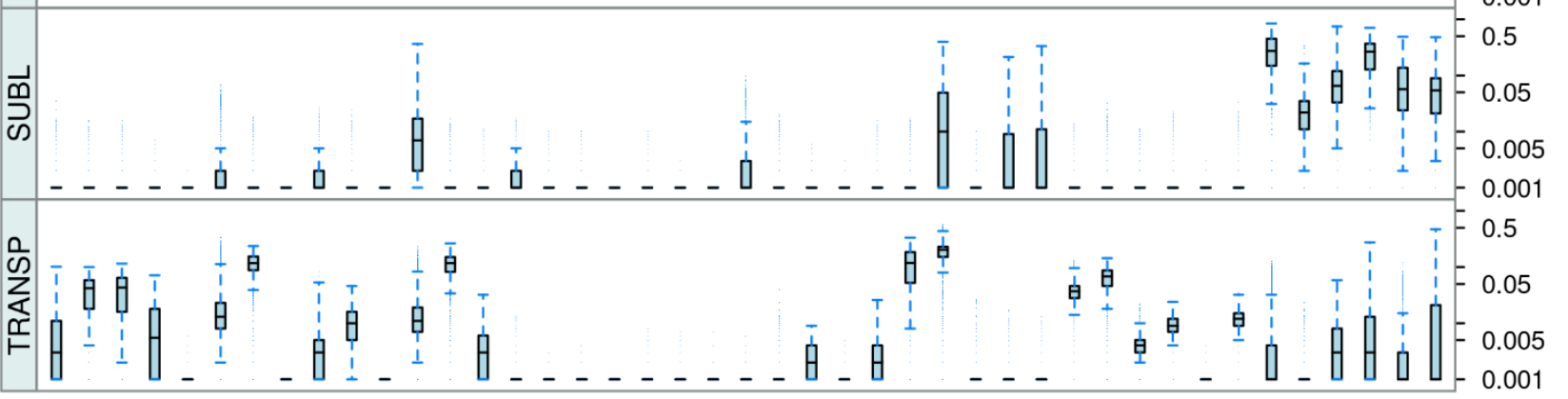

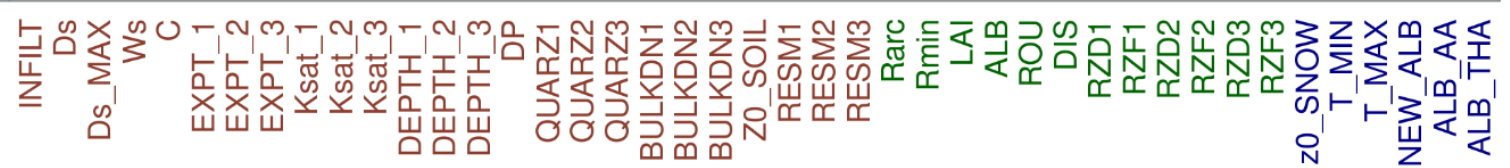

Figure 6. Boxplots comprising integrated first-order DELSA sensitivity indices $\left(I S_{j}^{L}\right)$ from all modeling units (5,574 grid cells). Results are displayed for all parameters (x-axis) and sensitivity metrics which are presented in different panels: (a) RMSE, (b) TRMSE; (c) FMS; (d) RR; (e) PeakSWE; (f) SnowLength; (g) SUBL; (h) TRANSP. 
https://doi.org/10.5194/hess-2021-550

Preprint. Discussion started: 22 November 2021

(c) Author(s) 2021. CC BY 4.0 License.

Hydrology and
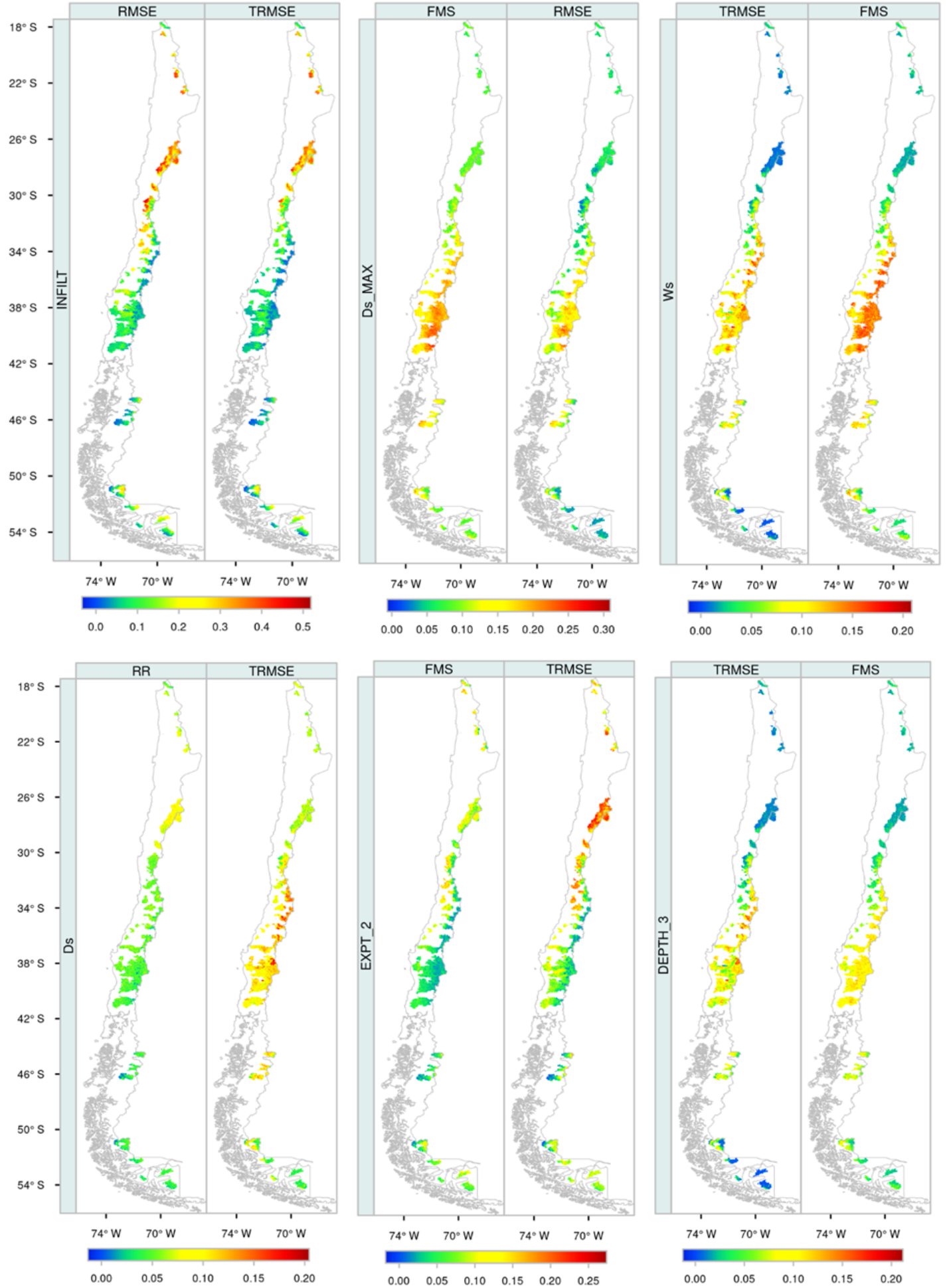

Figure 7. Integrated first-order DELSA sensitivity indices for all grid cells within our study basins. The results are displayed only the 12 most sensitive parameters, and their associated most impacted metrics. 
https://doi.org/10.5194/hess-2021-550

Preprint. Discussion started: 22 November 2021

(c) Author(s) 2021. CC BY 4.0 License.
Hydrology and

Earth System

Sciences

Discussions
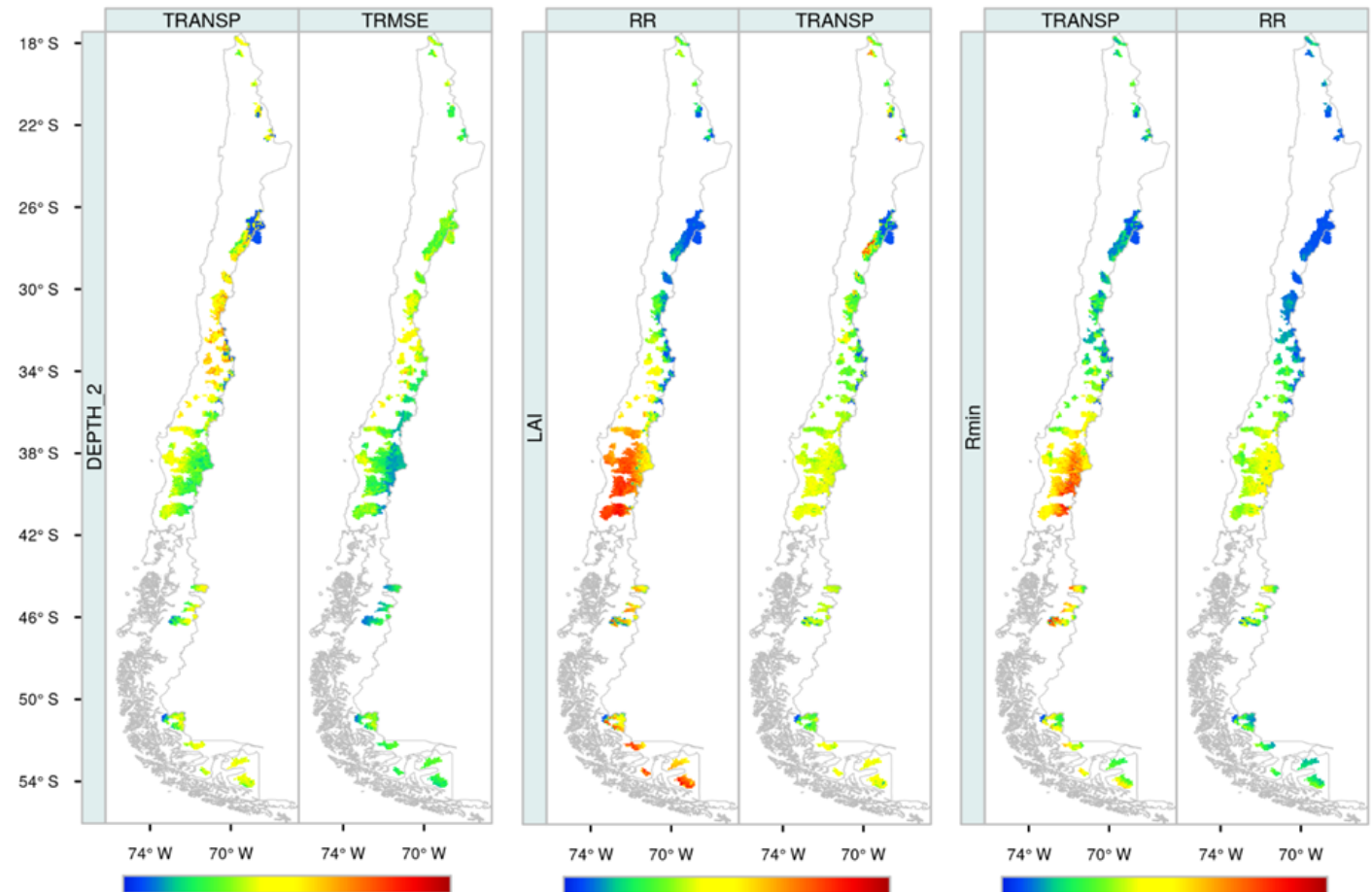

865

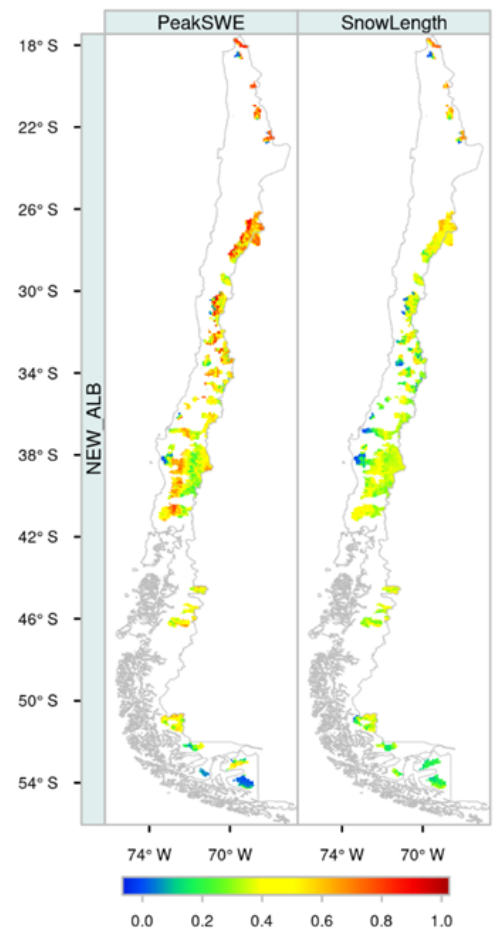

$\begin{array}{llllll}0.0 & 0.2 & 0.4 & 0.6 & 0.8 & 1.0\end{array}$

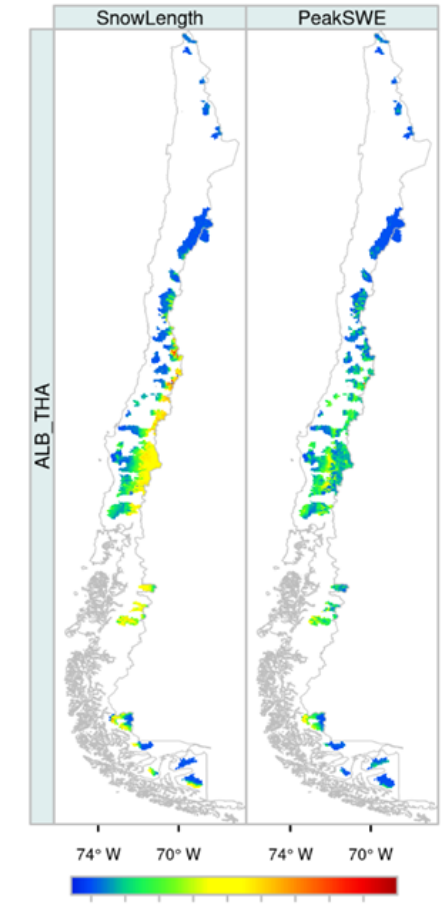

$\begin{array}{lllllllll}0.0 & 0.1 & 0.2 & 0.3 & 0.4 & 0.5 & 0.6 & 0.7 & 0.8\end{array}$

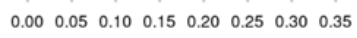

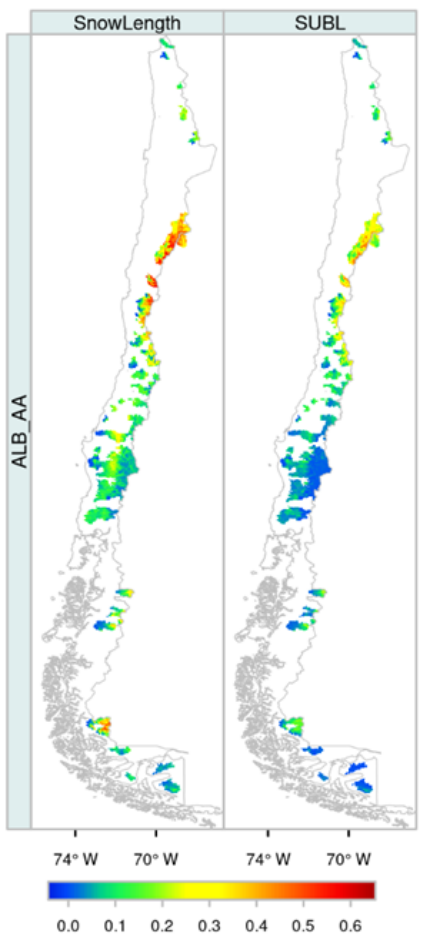

Figure 7. (continued). 
https://doi.org/10.5194/hess-2021-550

Preprint. Discussion started: 22 November 2021

(C) Author(s) 2021. CC BY 4.0 License.

(c) (i)
Hydrology and Earth System Sciences

Discussions

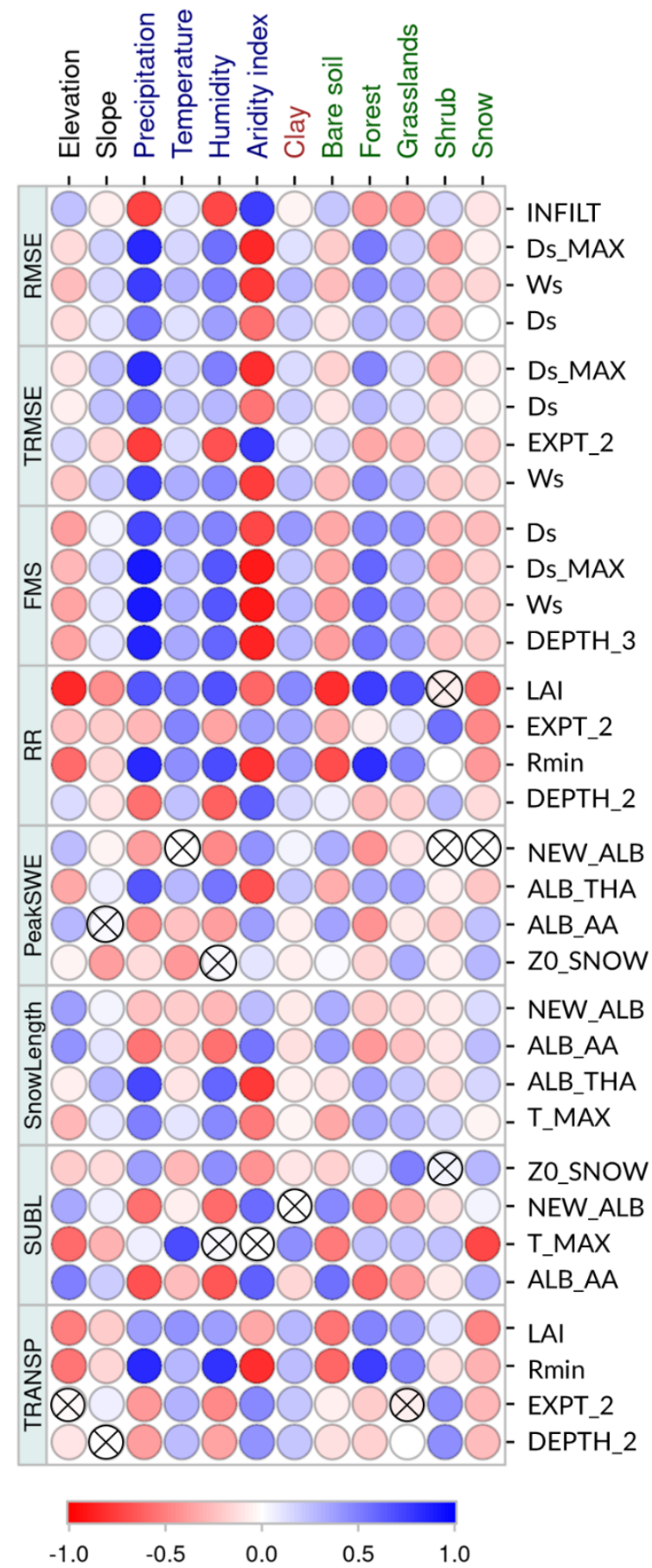

Figure 8. Spearman rank correlation coefficient between integrated first-order DELSA sensitivity indices $I S_{j}^{L}$ and grid cell characteristics. Results are displayed only for the four most sensitive parameters affecting each metric. The crosses indicate correlation values whose $p$-values are lower than 0.05 . 